Article

\title{
Biochemical Response of Oakleaf Lettuce Seedlings to Different Concentrations of Some Metal(oid) Oxide Nanoparticles
}

\author{
Rita Jurkow ${ }^{1, *}$, Agnieszka Sękara $\left.{ }^{1}{ }^{(}\right)$, Robert Pokluda ${ }^{2}\left(\mathbb{D}\right.$, Sylwester Smoleń ${ }^{3}{ }^{(\mathbb{D}}$ and \\ Andrzej Kalisz ${ }^{1}$ (D) \\ 1 Department of Horticulture, University of Agriculture in Krakow, 31-425 Kraków, Poland; \\ agnieszka.sekara@urk.edu.pl (A.S.); andrzej.kalisz@urk.edu.pl (A.K.) \\ 2 Department of Vegetable Sciences and Floriculture, Mendel University in Brno, \\ 69144 Lednice, Czech Republic; robert.pokluda@mendelu.cz \\ 3 Department of Plant Biology and Biotechnology, University of Agriculture in Krakow, \\ 31-425 Kraków, Poland; sylwester.smolen@urk.edu.pl \\ * Correspondence: r.jurkow@gmail.com
}

Received: 5 June 2020; Accepted: 9 July 2020; Published: 11 July 2020

\begin{abstract}
Nanoparticles (NPs) significantly modify the physiological functions and metabolome of plants. The purpose of the study was to investigate the effect of $\mathrm{CeO}_{2}, \mathrm{Fe}_{2} \mathrm{O}_{3}, \mathrm{SnO}_{2}, \mathrm{TiO}_{2}$, and $\mathrm{SiO}_{2}$ nanoparticles, applied in foliar spraying of oakleaf lettuce at concentrations $0.75 \%$ to $6 \%$, on the antioxidant enzyme activity and content of non-enzymatic antioxidants, chlorophyll pigments, fresh weight (FW) and dry weight (DW). It was found that $3 \% \mathrm{Fe}_{2} \mathrm{O}_{3}-\mathrm{NPs}$ caused a $27 \%$ decrease in fresh weight compared to control plants. $\mathrm{Fe}_{2} \mathrm{O}_{3}$-NPs caused an increase in dry weight ( $\left.\mathrm{g} 100 \mathrm{~g}^{-1} \mathrm{FW}\right)$ when compared to the control for all concentrations, but total DW (g per plant) was similar for all NPs treatments. Significant increases in chlorophyll $a+b$ content after treatment with $1.5 \%$ and $6 \%$ $\mathrm{SiO}_{2}-\mathrm{NPs}, 3 \% \mathrm{Fe}_{2} \mathrm{O}_{3}-\mathrm{NPs}$, and $3 \% \mathrm{TiO}_{2}-\mathrm{NPs}$ were noted. $\mathrm{Fe}_{2} \mathrm{O}_{3}-\mathrm{NPs}$ caused a significant increase in the activity of ascorbate peroxidase, guaiacol peroxidase, and catalase (only for $3 \% \mathrm{Fe}_{2} \mathrm{O}_{3}-\mathrm{NPs}$ ). $\mathrm{SnO}_{2}-\mathrm{NPs}$ decreased ascorbate peroxidase (APX) and guaiacol peroxidase (GPOX) activity (for all tested concentrations) but increased catalase (CAT) activity when a 3\% suspension of these NPs was applied. The level of glutathione (GSH) increased due to application of all metal/metalloid oxides, with the exception of $\mathrm{SnO}_{2}$-NPs. When all concentrations of $\mathrm{TiO}_{2}-\mathrm{NPs}$ were applied, L-ascorbic acid increased significantly, as well as increasing at higher concentrations of $\mathrm{SiO}_{2}-\mathrm{NPs}(3 \%$ and $6 \%)$ and at $0.75 \%$ and $3 \% \mathrm{Fe}_{2} \mathrm{O}_{3}$-NPs. $\mathrm{SiO}_{2}-\mathrm{NPs}$ and $\mathrm{TiO}_{2}-\mathrm{NPs}$ significantly elevated the carotenoid and total phenolic content in treated plants compared to the control. The total antioxidant capacity of plants treated with $3 \% \mathrm{CeO}_{2}-\mathrm{NPs}$ was almost twice as high as that of the control.
\end{abstract}

Keywords: abiotic stress; antioxidants; Lactuca sativa L. var. foliosa; foliar exposure; nanomaterials

\section{Introduction}

Nanoparticles (NPs) are atomic or molecular aggregates with at least one dimension in the range from 1 to $100 \mathrm{~nm}$ [1]. Metal or metalloid-based NPs (nanometals or nanoscale metal/metalloid oxides) belong to the engineered type of NPs and not only have unique chemical and physical properties in comparison to their bulk counterparts but also different biological actions [2]. Because of the widespread use of nanomaterials in industry and in consumer products, it is expected that NPs can be transferred and accumulated in aquatic, terrestrial, and atmospheric environments [3], where their fate and behavior seems to be unknown. The reactiveness of metal-based NPs in plants is determined by their metal compound, size, high surface-to-volume ratio, shape, and, most importantly, the dose at which they are 
effective [4]. After entering plant cells, NPs might directly provoke either alterations of membranes and other cell structures and molecules, or activity of protective mechanisms [5]. The indirect effects of NPs are caused inter alia by the release of toxic ions (e.g., metal ions), enhancement of the bioavailability of some toxic compounds, or by causing overproduction of reactive oxygen species (ROS) $[1,2,6]$.

It has been reported that the impact of NPs on plants can be diverse and depends on the type of NPs, their physicochemical properties, concentration, exposure time, and plant species [7]. Most studies have demonstrated that an excess of metal-based NPs can cause negative effects like reduced germination, dry weight, biomass, and transpiration, disturbances in the photosynthetic process, chlorophyll degradation, protein reduction, DNA damage, nutrient displacement, and others $[8,9]$. NPs trigger an oxidative burst by interfering with the electron transport chain and the production of ROS [1]. So it may be expected that the antioxidant defense mechanisms of plants based on ascorbate, glutathione, $\alpha$-tocopherol, or several enzymatic scavengers of ROS such as superoxide dismutase, peroxidases, and catalase, might provide protection against such adverse effects of NPs $[5,10]$. Besides the toxicity of NPs, they may also have some positive effects on plants. For example, $\mathrm{TiO}_{2}-\mathrm{NPs}$ have been found to induce spinach seed germination; moreover, during growth, the plant dry weight is increased, as are chlorophyll synthesis, ribulosebisphosphate carboxylase/oxygenase activity, and photosynthetic rate [11]. Positive or inconsequential effects of non-organic NPs on food crops have been already presented [6,8], but there is no full explanation of the mechanisms of NPs action. Taken together, the literature presents differentiated data on the impact of particular NPs on plants due to different sizes, concentrations, application routes etc., so the influence of NPs on plants still requires further investigation and standardizing research procedures.

Interactions between NPs and plants are a problem that we have to face in relation to rapidly developing nanotechnology. In our study we focused on the exposure of plant leaves to different metal oxide and metalloid oxide nanoparticles (MO-NPs) with various physicochemical properties, applied at different concentrations. We chose five commercial nanoparticles of metal oxides/metalloid oxide, including four nanoparticles $\left(\mathrm{CeO}_{2}, \mathrm{Fe}_{2} \mathrm{O}_{3}, \mathrm{TiO}_{2}\right.$, and $\left.\mathrm{SiO}_{2}\right)$ for which there are certain data on their impact (beneficial or negative) on plants and one nanoparticle $\left(\mathrm{SnO}_{2}\right)$ with an indistinct role and impact on plants. Our assumption was that NPs treatment will cause abiotic stress followed by activation of antioxidative mechanisms. Moreover, the operation of these mechanisms and the intensity of the stress will be different depending on the type of MO-NPs applied and the concentration used.

\section{Materials and Methods}

\subsection{Characteristics of Nanoparticles}

The MO-NPs utilized in this study are commercially available from PlasmaChem $\mathrm{GmbH}$ (Berlin, Germany) as aqueous suspensions. Nanoparticles of cerium oxide $\left(\mathrm{CeO}_{2}-\mathrm{NPs}\right)$, iron (III) oxide $\left(\alpha-\mathrm{Fe}_{2} \mathrm{O}_{3}-\mathrm{NPs}\right)$, silicon dioxide $\left(\mathrm{SiO}_{2}-\mathrm{NPs}\right)$, tin(IV) oxide $\left(\mathrm{SnO}_{2}-\mathrm{NPs}\right)$, and titanium(IV) dioxide $\left(\mathrm{TiO}_{2}-\mathrm{NPs}\right)$ were used in the experiment. The basic characteristics of $\mathrm{NPs}$ are: $\mathrm{CeO}_{2}-\mathrm{NPs}-$ average particle size: $4 \pm 2 \mathrm{~nm}$, specific surface area: ca. $20 \mathrm{~m}^{2} \mathrm{~g}^{-1} ; \mathrm{Fe}_{2} \mathrm{O}_{3}-\mathrm{NPs}-$ hematite phase, average particle size: $6 \pm 2 \mathrm{~nm}$; $\mathrm{SiO}_{2}-\mathrm{NPs}$ - average particle size: ca. $10 \mathrm{~nm}$, specific surface area: ca. $320 \mathrm{~m}^{2} \mathrm{~g}^{-1}$; $\mathrm{SnO}_{2}-\mathrm{NPs}$-average particle size: $6 \pm 2 \mathrm{~nm}$; $\mathrm{TiO}_{2}-\mathrm{NPs}$-anatase phase, average particle size: $6 \pm 2 \mathrm{~nm}$, specific surface area: ca. $140 \mathrm{~m}^{2} \mathrm{~g}^{-1}$. All MO-NPs were delivered as $5 \mathrm{wt} \%$ aqueous colloidal suspensions with the exception of $\mathrm{SiO}_{2}-\mathrm{NPs}(30 \mathrm{wt} \%)$. In this study, several concentrations of MO-NP suspensions were prepared (see next section) by adding deionized water to the stock suspension.

\subsection{Plant Material and Nanoparticle Application}

Seedlings of oakleaf lettuce (Lactuca sativa L. var. foliosa Bremer) cv. Kiribati (seeds from Rijk Zwaan Polska Sp. z o.o., Warszawa, Poland) were purchased from the Krasoń vegetable seedling producers group (Piaski, Poland). We chose this plant because of its fairly large importance as a salad crop, its rapid growth and delicate leaves of large leaf surface, without wax coating, making it a 
good model for testing effects of foliar exposure to nanoparticles. Lettuce is a plant often taken into account in studying response to different stresses, including studies of metabolism alterations caused by nanoparticles $[12,13]$. Production of oakleaf lettuce seedlings takes around 3 weeks from sowing to planting out.

Seeds were sown into cubic peat pots (dimensions $4 \times 4 \times 4 \mathrm{~cm}$, total volume of $64 \mathrm{~cm}^{3}$ ) placed in plastic boxes (150 pots per box in total). During cultivation, $0.3 \%$ solution of Goëmar Goteo (Arysta LifeScience Polska Sp. z o.o., Warsaw, Poland) was applied once as a plant biostimulator. Goëmar Goteo contains $13 \% \mathrm{P}_{2} \mathrm{O}_{5}, 5 \% \mathrm{~K}_{2} \mathrm{O}$ and Ascophyllum nodosum filtrate. Two-week-old seedlings (4-5 leaves) were placed on a table in a greenhouse and the plants were irrigated by flooding the table. If necessary, flooded irrigation was used during the experiment. After 2 more days, the following concentrations of NPs were applied to the leaf surface, using a hand sprayer with a mist spray nozzle: $6 \%, 3 \%$, and $1.5 \%$ of $\mathrm{TiO}_{2}$ and $\mathrm{SiO}_{2} ; 3 \%$ and $1.5 \%$ of $\mathrm{CeO}_{2}, \mathrm{SnO}_{2}$, and $\mathrm{Fe}_{2} \mathrm{O}_{3} ; 0.75 \% \mathrm{Fe}_{2} \mathrm{O}_{3}$ was also used. Based on preliminary tests (the seedlings having 3-4 leaves were sprayed with different concentrations of nanoparticles), the highest applied NPs concentrations that did not cause severe leaf necroses and plant deformation (visual estimation) were selected for further experiments. Next, 1-2 lower concentrations were prepared and used to determine whether also nanoparticles in a more diluted suspension will affect metabolic processes in plants. For each treatment, there were three plastic seedling boxes with 150 plants per box (450 plants per treatment); particular suspensions were applied evenly on the leaves in a dose of $50 \mathrm{~cm}^{3}$ per box (ca. $0.33 \mathrm{~cm}^{3}$ per plant). Control plants were sprayed at the same time with deionized water. No additional fertilization was used during trial. Plant samples for laboratory analyses were taken after 7 days. Leaves were washed with tap water and rinsed with deionized water. Then all leaves from a treatment were mixed, fresh laboratory samples were taken from these leaves to determine dry weight, L-ascorbic acid and glutathione. The rest of the collected leaves were inserted into an ultra-deep freezer to a temperature of $-40^{\circ} \mathrm{C}$ for further chemical analyses.

\subsection{Fresh and Dry Weight}

The above-ground plants were weighed with a Sartorius A120S balance (Sartorius AG, Göttingen, Germany) to determine fresh weight (FW) and oven-dried at $65{ }^{\circ} \mathrm{C}$ until constant weight to determine dry weight (DW). Then, the difference in weight was calculated and expressed as the FW percentage. DW content was also re-calculated and presented in grams per plant shoot.

\subsection{Chlorophyll and Carotenoid Content}

The chlorophyll ( $a$ and $b$ ) and carotenoid content was determined 7 days after NP treatment according to the procedure of Lichtenthaler and Wellburn [14]. Leaf samples $(0.1 \mathrm{~g})$ were ground with the addition of $3 \mathrm{mg}$ of magnesium carbonate $\left(\mathrm{MgCO}_{3}\right)$ as a pigment stabilizer, and chlorophyll (Chl $a$ and $\mathrm{Chl} b$ ) and carotenoids (Car) were extracted in $80 \%(v / v)$ aqueous acetone $\left(25 \mathrm{~cm}^{3}\right)$. After $0.5 \mathrm{~h}$ incubation in the dark, the suspension obtained was filtered through a filter paper (POCH SA, No. 978774513, Gliwice, Poland). Absorbance was determined at wavelengths of 646, 663, and $470 \mathrm{~nm}$ using a spectrophotometer (UV-VIS Helios Beta, Thermo Fisher Scientific Inc., Waltham, USA). Absorption measurements were used to quantify the chlorophyll $a$, chlorophyll $b$, and total carotenoid content, based on the equations reported by Lichtenthaler and Wellburn [14]. Additionally, the total chlorophyll $(a+b)$ content and the ratios of chlorophyll $a$ to chlorophyll $b(\mathrm{Chl} a: \mathrm{Chl} b)$ and of carotenoids to total chlorophylls (Car:Chls) were also calculated.

\subsection{Antioxidant Enzyme Assays}

Catalase (CAT, EC 1.11.1.6) activity was determined according to Aebi [15]. Leaves (5 g) were ground in an ice bath $\left(4{ }^{\circ} \mathrm{C}\right)$ with $10 \mathrm{~cm}^{3}$ of extraction buffer $(0.05 \mathrm{M}$ potassium phosphate buffer). The extract was centrifuged for $15 \mathrm{~min}$ at $3492 \mathrm{~g}$ and $4{ }^{\circ} \mathrm{C}$. Test tubes contained $1.8 \mathrm{~cm}^{3}$ of $0.05 \mathrm{M}$ phosphate buffer ( $\mathrm{pH} 7.0$ ) and $1.0 \mathrm{~cm}^{3}$ of $0.05 \% \mathrm{H}_{2} \mathrm{O}_{2}$ solution in $0.05 \mathrm{M}$ potassium phosphate buffer (pH 7.0). The supernatant $\left(0.2 \mathrm{~cm}^{3}\right)$ was used for enzymatic assays. CAT activity was estimated by 
the decrease in absorbance of $\mathrm{H}_{2} \mathrm{O}_{2}$ against a blank at wavelength of $240 \mathrm{~nm}$ (UV-VIS Helios Beta spectrophotometer) over a period of $5 \mathrm{~min}$ and expressed in $\mu \mathrm{mol}$ of $\mathrm{H}_{2} \mathrm{O}_{2} \min ^{-1} \mathrm{~g}^{-1} \mathrm{FW}$.

The procedure for determining ascorbate peroxidase and guaiacol peroxidase activity started with preparation of a mixture at $4{ }^{\circ} \mathrm{C}$ containing $4 \mathrm{~g}$ of leaf samples homogenized in $10 \mathrm{~cm}^{3}$ of $50 \mathrm{mM}$ potassium phosphate buffer ( $\mathrm{pH}$ 7.0) with $1 \mathrm{mM}$ ethylenediaminetetraacetic acid (EDTA), $1 \%$ soluble polyvinyl pyrrolidone (PVP), and $1 \mathrm{mM}$ phenylmethylsulfonyl fluoride (PMSF). The mixture was centrifuged at $13,968 \mathrm{~g}$ for $15 \mathrm{~min}$ at $4{ }^{\circ} \mathrm{C}$, and the supernatant $\left(0.4 \mathrm{~cm}^{3}\right.$ for guaiacol peroxidase and $0.5 \mathrm{~cm}^{3}$ for ascorbate peroxidase assay) was used for enzyme activity assays. The activity of ascorbate peroxidase (APX, EC 1.11.1.11) was measured using the method of Nakano and Asada [16]. The reaction mixture consisted of $50 \mathrm{mM}$ potassium phosphate buffer ( $\mathrm{pH} 7.0$ ) containing $0.5 \mathrm{mM}$ ascorbate, $0.1 \mathrm{mM} \mathrm{H}_{2} \mathrm{O}_{2}$, and $0.15 \mathrm{~cm}^{3}$ of the enzyme extract. Oxidation of ascorbate detected as a decrease in absorbance at $290 \mathrm{~nm}$ (UV-VIS Helios Beta spectrophotometer) was followed $5 \mathrm{~min}$ after starting the reaction. The difference in absorbance was divided by the ascorbate molar extinction coefficient $\left(\varepsilon=2.8 \mathrm{mM}^{-1} \mathrm{~cm}^{-1}\right)$. The activity of the enzyme was expressed as $\mu \mathrm{g}$ ascorbate (AsA) $\mathrm{min}^{-1} \mathrm{~g}^{-1} \mathrm{FW}$. The activity of guaiacol peroxidase (GPOX, EC 1.11.1.7) was assayed according to Zhang et al. [17], based on the oxidation of guaiacol using hydrogen peroxide. The reaction mixture consisted of $50 \mathrm{mM}$ phosphorus buffer ( $\mathrm{pH} 7.0)$, hydrogen peroxide (1\%), and guaiacol (4\%). The reaction was started by adding $0.4 \mathrm{~cm}^{3}$ of enzyme extract to the reaction mixture at $25{ }^{\circ} \mathrm{C}$; GPOX activity was measured by the increase in absorbance at $470 \mathrm{~nm}$ due to guaiacol oxidation using a UV-VIS Helios Beta spectrophotometer over a period of $3 \min \left(\varepsilon=26.6 \mathrm{mM}^{-1} \mathrm{~cm}^{-1}\right)$. The activity level was expressed as $\mu \mathrm{mol}$ tetraguaiacol $\mathrm{min}^{-1} \mathrm{~g}^{-1} \mathrm{FW}$.

\subsection{Glutathione Content}

The reduced form of glutathione (GSH) was determined according to the method described by Guri [18] with modifications. Fresh leaf tissue $(2.5 \mathrm{~g})$ was homogenized in an ice bath $\left(4{ }^{\circ} \mathrm{C}\right)$ with the addition of $6 \mathrm{~cm}^{3}$ of $0.5 \mathrm{mM}$ EDTA and 3\% trichloroacetic acid (TCA) and the homogenate was centrifuged at $4{ }^{\circ} \mathrm{C}$ for $10 \mathrm{~min}$ at $6208 \mathrm{~g}$. In order to bring the $\mathrm{pH}$ of the solution to ca. 7.0, K-phosphate buffer was used. The content of reduced GSH was assessed using Ellman's reagent (5,5-dithiobis-2-nitrobenzoic acid, DTNB) on a UV-VIS Helios Beta spectrophotometer. The solution extinction was measured at the wavelength $\lambda=412 \mathrm{~nm}$. The absorbance of a mixture of $2.0 \mathrm{~cm}^{3}$ of plant homogenate and $1.0 \mathrm{~cm}^{3}$ of $0.2 \mathrm{M} \mathrm{K}$-phosphate buffer, which absorbed part of the radiation, was measured as a blind sample. The concentration of GSH was calculated from the standard curve and expressed as $\mu \mathrm{g} \mathrm{g}^{-1} \mathrm{FW}$.

\subsection{L-ascorbic Acid Content}

The content of L-ascorbic acid was determined by Tillman's titration method as described by Krełowska-Kułas [19]. Fresh plant leaves $(12.5 \mathrm{~g})$ were homogenized with $50 \mathrm{~cm}^{3}$ acetic acid applied as an acidity regulator. After $30 \mathrm{~min}$, the mixture was titrated with Tillman's reagent (2,6-dichlorophenol-indophenol). Excessive dye in an acidic environment gives a pink color and marks the end point of the titration. Then, the content of L-ascorbic acid in the sample was calculated based on the amount of the changed solution of 2,6-dichlorophenol-indophenol used for titration.

\subsection{Total Phenolic Content}

The concentration of total phenols in plant extracts was estimated by the Folin-Ciocalteu colorimetric procedure described by Djeridane et al. [20] with modifications. Two grams of plant material was mixed with $10 \mathrm{~cm}^{3}$ of $80 \%$ methanol and centrifuged for $10 \mathrm{~min}$ at $3492 \mathrm{~g}$. Next, plant extracts $\left(0.1 \mathrm{~cm}^{3}\right)$ were mixed with $2 \mathrm{~cm}^{3}$ of $2 \%$ sodium carbonate $\left(\mathrm{Na}_{2} \mathrm{CO}_{3}\right)$; after $2 \mathrm{~min}, 0.1 \mathrm{~cm}^{3}$ of Folin-Ciocalteu reagent, mixed with deionized water $(1: 1 v / v)$, was added to the test tubes. The final mixture was shaken and then incubated for $45 \mathrm{~min}$ in the dark at room temperature before measuring the absorbance at $750 \mathrm{~nm}$ using a UV-VIS Helios Beta spectrophotometer against a reference solution. 
The results were determined from a standard gallic acid curve and expressed as milligrams of gallic acid equivalents (GAE) per gram FW (mg GAE g $\left.{ }^{-1} \mathrm{FW}\right)$.

\section{9. $\mathrm{DPPH} H^{\bullet}$ Radical Scavenging Activity}

The antioxidant activity (AA) was determined using 2,2-diphenyl-1-picrylhydrazyl (DPPH ${ }^{\bullet}$ ) as a free radical [21]. The decrease in absorbance was measured at $517 \mathrm{~nm}$ with a UV-VIS Helios Beta spectrophotometer. Ground plant material $(2.5 \mathrm{~g})$ in $80 \%$ methanol was centrifuged $(3492 \mathrm{~g}, 10 \mathrm{~min}$ at $4{ }^{\circ} \mathrm{C}$ ). The test tubes contained $0.1 \mathrm{~mL}$ of supernatant and $4.9 \mathrm{~mL}$ of $0.1 \mathrm{mM} \mathrm{DPPH}^{\bullet}$ dissolved with $80 \%$ methanol. The reaction mixture was shaken and incubated in the dark at $20^{\circ} \mathrm{C}$ for $15 \mathrm{~min}$. The following formula was used to calculate $\mathrm{DPPH}^{\bullet}$ radical scavenging activity: $\mathrm{AA}[\%]=\left[\left(\mathrm{A}_{0}-\mathrm{A}_{1}\right) / \mathrm{A}_{0}\right] \times 100$; AA—antioxidant activity, $\mathrm{A}_{0}$-absorbance of the reference solution, $\mathrm{A}_{1}$-absorbance of the test solution. AA was expressed as the percentage of $\mathrm{DPPH}^{\bullet}$ free radical scavenging.

\subsection{Content of $\mathrm{Ce}, \mathrm{Fe}, \mathrm{Si}, \mathrm{Sn}$, and $\mathrm{Ti}$}

Plant material (finely chopped lettuce leaves, sampled as described earlier) was oven-dried at $65^{\circ} \mathrm{C}$, to a constant weight, and ground to a fine powder using a Pulverisette 14 ball mill (Fritsch $\mathrm{GmbH}$, Idar-Oberstein, Germany) with a $0.5 \mathrm{~mm}$ sieve. The total content of the elements $\mathrm{Ce}, \mathrm{Fe}, \mathrm{Si}, \mathrm{Sn}$, and Ti was analyzed in ground samples of lettuce leaves. Before determination of the elements by spectrometric technique, microwave mineralization of the samples was executed. A separate two-step digestion was used for mineralization of the samples for the determination of $\mathrm{Si}$ than for the digestion of samples for the analysis of the total content of $\mathrm{Ce}, \mathrm{Fe}, \mathrm{Sn}$, and Ti. A Mars 5 Xpress microwave digestion system (CEM Corporation, Matthews, NC, USA) and $100 \mathrm{~cm}^{3}$ TFM vessels were used.

The Si analysis was performed using a Prodigy ICP-OES spectrometer (Teledyne Leeman Labs, Hudson, NH, USA). It was preceded by two-stage microwave mineralization of samples according to the method of Barros et al. [22]. In the first stage, $100 \mathrm{mg}$ lettuce samples were placed in TFM vessels and mineralized in $5 \mathrm{~mL}$ of $1 \mathrm{M}$ super-pure $\mathrm{HNO}_{3}$ (Merck no. 100443.2500) plus $5 \mathrm{~mL}$ of $\mathrm{H}_{2} \mathrm{O}_{2}(30 \% \mathrm{v} / \mathrm{v})$ in a microwave digestion system. The following mineralization procedure was applied: $5 \mathrm{~min}$ to achieve a temperature of $120^{\circ} \mathrm{C}$ which was maintained for $5 \mathrm{~min} ; 5 \mathrm{~min}$ to reach $160^{\circ} \mathrm{C}$ which was maintained for $5 \mathrm{~min} ; 3 \mathrm{~min}$ to reach $230^{\circ} \mathrm{C}$ which was maintained for $5 \mathrm{~min}$. The second stage was after cooling, when the TFM vessels were open and $5 \mathrm{~mL}$ of $1.5 \mathrm{M} \mathrm{NaOH}$ was added to the mineralized sample in the TFM vessel. The following program was used for mineralization in the second stage of digestion: $5 \mathrm{~min}$ to reach $150^{\circ} \mathrm{C}$ which was maintained for $5 \mathrm{~min} ; 5 \mathrm{~min}$ to reach $230{ }^{\circ} \mathrm{C}$ which was maintained for $10 \mathrm{~min}$. After cooling, the samples were quantitatively transferred to $50 \mathrm{~mL}$ graduated flasks with $14 \mathrm{M} \mathrm{HNO}_{3}$.

In order to determine the content of $\mathrm{Ce}, \mathrm{Fe}, \mathrm{Sn}$, and $\mathrm{Ti}$, plant samples $(3 \mathrm{~g})$ were placed into $100 \mathrm{~cm}^{3}$ TFM vessels and mineralized in $10 \mathrm{~cm}^{3}$ of $65 \%$ super-pure $\mathrm{HNO}_{3}$ (Merck no. 100443.2500) in a Mars 5 Xpress microwave digestion system according to the method described in a previous publication [23]. After cooling, the samples were quantitatively transferred to $25 \mathrm{~cm}^{3}$ graduated flasks with redistilled water. These four elements were analyzed using an iCAP TQ ICP-MS/MS triple quadrupole spectrometer (ThermoFisher Scientific, Bremen, Germany). Determination was carried out using the following measurement modes for individual isotopes of elements: S-SQ-KED for ${ }^{56} \mathrm{Fe}$, ${ }^{118} \mathrm{Sn}$, and ${ }^{49} \mathrm{Ti}$ and S-TQ-O2 for ${ }^{140} \mathrm{Ce}$, and ${ }^{16} \mathrm{O}$.

\subsection{Statistical Analysis}

The data obtained from this study were analyzed using Statistica 13.3 (TIBCO Software Inc., Palo Alto, CA, USA). Each nanoparticle was treated as a separate part of the experiment and were not statistically compared to each other, only to control. Differences between particular treatments (specific nanoparticle and its concentrations) and untreated control were analyzed using one-way ANOVA and Fisher post-hoc test. A $p$-value of less or equal than 0.05 was considered to be statistically significant. Means for concentrations of given MO-NPs followed by different letters are significantly 
different at $p \leq 0.05$, comparisons were performed using the Fisher test. Data for each measurement represent the mean of three biological replicates \pm standard deviation (SD). Based on the activity of antioxidant enzymes and the content of non-enzymatic antioxidants, principal component analysis (PCA) was performed using Statistica 13.3 software (data were standardized before starting the analysis procedure) and the first two components (PC1 and $\mathrm{PC} 2$ ) explaining the maximum variance in the datasets were used to make biplots.

\section{Results}

A comparison was made on fresh and dry weights (per plants) and dry weight (g $\left.100 \mathrm{~g}^{-1} \mathrm{FW}\right)$ in response to nanoparticle treatments. Treatment of oakleaf lettuce seedlings with MO-NPs at different concentrations usually did not have a significant effect on the fresh weight (FW) of the plants in comparison to the control (Table 1). Only plants sprayed with $3 \% \mathrm{Fe}_{2} \mathrm{O}_{3}$-NPs responded with a $27.1 \%$ decrease in FW compared to control plants. Dry weight (DW) (g $100 \mathrm{~g}^{-1} \mathrm{FW}$ ) increased when compared to the control for all tested concentrations of $\mathrm{Fe}_{2} \mathrm{O}_{3}-\mathrm{NPs}$, indicating higher plant dehydration, especially after treatment with $3 \%$ suspension (in that case, the difference amounted to

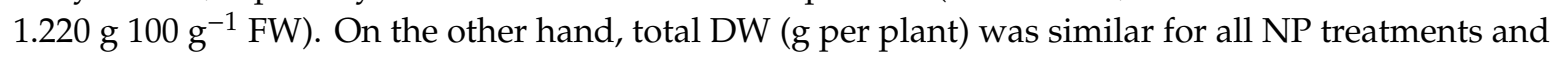
control, which pointed to no disturbances in anabolic processes efficiency.

There were significant increases in chlorophyll $a$ content after treatment with the following NPs: $3 \% \mathrm{Fe}_{2} \mathrm{O}_{3}-\mathrm{NPs}, 3 \% \mathrm{TiO}_{2}-\mathrm{NPs}$, and $\mathrm{SiO}_{2}-\mathrm{NPs}$ (all concentrations tested: $1.5 \%, 3 \%, 6 \%$ ). The differences between these treatments and the control were $0.063,0.154,0.161,0.065$, and $0.161 \mathrm{mg} \mathrm{g}^{-1} \mathrm{FW}$, respectively. $\mathrm{SiO}_{2}-\mathrm{NPs}$ applied in a concentration of $1.5 \%$ and $6 \%$ increased the chlorophyll $a$ content more than with a concentration of $3 \%$ of these nanoparticles. Applying $\mathrm{SiO}_{2}-\mathrm{NPs}$ to plant leaves at $1.5 \%$ and $6 \%$ caused significant increase in chlorophyll $b$ concentration (by 0.027 and 0.026 , respectively) compared to the control. $\mathrm{Fe}_{2} \mathrm{O}_{3}$-NPs used in a concentration of $3 \%$ increase chlorophyll $b$ more than using a suspension of $0.75 \%$, Compared to control, changes in chlorophyll $b$ content of lettuce sprayed with $\mathrm{Fe}_{2} \mathrm{O}_{3}-\mathrm{NPs}$ were, however, negligible. As a result of foliar spraying with $3 \% \mathrm{TiO}_{2}-\mathrm{NPs}$, $3 \% \mathrm{Fe}_{2} \mathrm{O}_{3}-\mathrm{NPs}$, and $\mathrm{SiO}_{2}-\mathrm{NPs}$ at concentrations of $1.5 \%$ and $6 \%$, total chlorophyll content significantly increased from $0.078 \mathrm{mg} \mathrm{g}^{-1} \mathrm{FW}\left(3 \% \mathrm{Fe}_{2} \mathrm{O}_{3}-\mathrm{NPs}\right)$ to $0.188 \mathrm{mg} \mathrm{g}^{-1} \mathrm{FW}\left(1.5 \% \mathrm{SiO}_{2}-\mathrm{NPs}\right)$ in comparison to the control. The highest chlorophyll $a$ :chlorophyll $b$ ratio $(\mathrm{Chl} a: \mathrm{Chl} b)$ as well as carotenoids to chlorophylls ratio (Car:Chls) was an effect of the treatment with all concentrations of $\mathrm{SiO}_{2}-\mathrm{NPs}_{\mathrm{s}}$ and $\mathrm{TiO}_{2}-\mathrm{NPs}$ (for $\mathrm{Chl} a: \mathrm{Chl} b$ ratio not for $1.5 \% \mathrm{TiO}_{2}-\mathrm{NPs}$ ).

A significant increase in ascorbate peroxidase (APX) activity was observed at all concentrations of $\mathrm{Fe}_{2} \mathrm{O}_{3}$-NPs (Figure 1A). The greatest difference in APX activity was observed between control plants and oakleaf lettuce treated with $3 \% \mathrm{Fe}_{2} \mathrm{O}_{3}$-NPs, reaching a level of $158.1 \%$. Foliar application of $\mathrm{CeO}_{2}-\mathrm{NPs}$ in the form of a $1.5 \%$ suspension decreased APX activity by $32.3 \%$. Plants treated with $1.5 \%$ and $3 \% \mathrm{SnO}_{2}$ showed a decrease in APX activity (by $25.8 \%$ and $40.3 \%$, respectively). $\mathrm{TiO}_{2}-\mathrm{NPs}$ applied at $1.5 \%$ and $3 \%$ also decreased APX activity by $25.8 \%$ and $29.0 \%$, respectively. $\mathrm{SiO}_{2}-\mathrm{NPs}$ used in a concentration of $1.5 \%$ increased the activity APX more than with a suspension having a concentration of $3 \%$. Similar to that of APX, guaiacol peroxidase (GPOX) activity also increased in lettuce as a result of foliar spraying with all tested concentrations of $\mathrm{Fe}_{2} \mathrm{O}_{3}$-NPs (Figure 1B). Plants treated with $3 \%$ $\mathrm{Fe}_{2} \mathrm{O}_{3}$-NPs had $246.0 \%$ higher GPOX enzyme activity than control plants. Moreover, GPOX activity gradually increased with an increasing concentration of $\mathrm{Fe}_{2} \mathrm{O}_{3}$-NPs. Additionally, spraying plants with $6 \% \mathrm{SiO}_{2}-\mathrm{NPs}$ and $6 \% \mathrm{TiO}_{2}-\mathrm{NPs}$ caused a $74.2 \%$ and $25.3 \%$, respectively, increase in GPOX activity, in comparison to the control. Treatment with all tested concentrations of $\mathrm{SnO}_{2}-\mathrm{NPs}(1.5 \%$ and $3 \%)$ significantly decreased the activity of this enzyme, by $61.1 \%$ and $38.4 \%$ when compared to control. The highest catalase (CAT) activity occurred in plants treated with $\mathrm{Fe}_{2} \mathrm{O}_{3}-\mathrm{NPs}$ (Figure 1C), when a $3 \%$ suspension was used (the difference reached $387.5 \%$ in comparison to the control). Additionally, $3 \% \mathrm{SnO}_{2}$ caused significant increase (by $100.0 \%$ ) in CAT activity compared to control. 
Table 1. Fresh and dry weight of oakleaf lettuce seedlings, content of chlorophyll pigments in the plants, and Chl $a$ :Chl $b$ and Car:Chls ratios depending on engineered nanoparticles (nano-metal/metalloid oxides; MO-NPs) applied to the leaves at different concentrations. Control plants were sprayed with deionized water.

\begin{tabular}{|c|c|c|c|c|c|c|c|c|c|}
\hline \multicolumn{2}{|c|}{$\begin{array}{l}\text { MO-NPs and } \\
\text { Concentration }\end{array}$} & \multirow{3}{*}{$\begin{array}{c}\begin{array}{c}\text { Fresh Weight } \\
\text { (g per shoot) }\end{array} \\
2.850 \pm 0.262 \\
2.851 \pm 0.263\end{array}$} & \multirow{3}{*}{$\begin{array}{c}\begin{array}{c}\text { Dry Weight } \\
\text { (g 100 g-1 FW) }\end{array} \\
3.309 \pm 0.226 \\
3.596 \pm 0.090\end{array}$} & \multirow{3}{*}{$\begin{array}{c}\begin{array}{c}\text { Total Dry Weight } \\
\text { (g per shoot) }\end{array} \\
0.094 \pm 0.011 \\
0.103 \pm 0.012\end{array}$} & \multirow{3}{*}{ 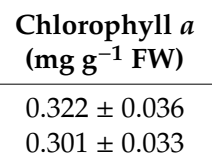 } & \multirow{3}{*}{$\begin{array}{c}\begin{array}{c}\text { Chlorophyll } \boldsymbol{b} \\
\text { (mg g }^{-1} \text { FW) }\end{array} \\
0.134 \pm 0.011 \\
0.125 \pm 0.019\end{array}$} & \multirow{3}{*}{$\begin{array}{c}\begin{array}{c}\text { Chlorophyll } a+b \\
\text { (mg g }^{-1} \text { FW) }\end{array} \\
0.456 \pm 0.041 \\
0.426 \pm 0.046\end{array}$} & \multirow{3}{*}{$\begin{array}{c}\begin{array}{c}\text { Chl } a: \text { Chl } b \\
\text { Ratio }\end{array} \\
2.403 \pm 0.290 \\
2.408 \pm 0.282\end{array}$} & \multirow{3}{*}{$\begin{array}{c}\text { Car:Chls Ratio } \\
0.149 \pm 0.016 \\
0.143 \pm 0.017\end{array}$} \\
\hline $\mathrm{CeO}_{2}$ & $1.5 \%$ & & & & & & & & \\
\hline & $3 \%$ & & & & & & & & \\
\hline \multirow[t]{3}{*}{$\mathrm{Fe}_{2} \mathrm{O}_{3}$} & $0.75 \%$ & $2.821 \pm 0.315$ & $3.957 \pm 0.196 * a$ & $0.111 \pm 0.008$ & $0.272 \pm 0.009 \mathrm{a}$ & $0.105 \pm 0.007 \mathrm{a}$ & $0.377 \pm 0.007 \mathrm{a}$ & $2.591 \pm 0.231$ & $0.152 \pm 0.019$ \\
\hline & $1.5 \%$ & $2.629 \pm 0.476$ & $3.999 \pm 0.073 * a$ & $0.105 \pm 0.017$ & $0.290 \pm 0.006 \mathrm{a}$ & $0.117 \pm 0.002 \mathrm{ab}$ & $0.407 \pm 0.005 \mathrm{a}$ & $2.479 \pm 0.096$ & $0.149 \pm 0.005$ \\
\hline & $3 \%$ & $2.208 \pm 0.386^{*}$ & $4.567 \pm 0.276^{*} \mathrm{~b}$ & $0.100 \pm 0.015$ & $0.333 \pm 0.029 * b$ & $0.125 \pm 0.009 \mathrm{~b}$ & $0.458 \pm 0.038 * b$ & $2.664 \pm 0.053$ & $0.149 \pm 0.004$ \\
\hline \multirow[t]{2}{*}{$\mathrm{SiO}_{2}$} & $1.5 \%$ & $3.305 \pm 0.407$ & $3.471 \pm 0.015$ & $0.115 \pm 0.015$ & $0.431 \pm 0.025 * b$ & $0.137 \pm 0.008 * b$ & $0.568 \pm 0.034 * b$ & $3.146 \pm 0.048 *$ & $0.195 \pm 0.016 * b$ \\
\hline & $3 \%$ & $3.325 \pm 0.057$ & $3.603 \pm 0.045$ & $0.120 \pm 0.001$ & $0.335 \pm 0.023 * a$ & $0.107 \pm 0.006 \mathrm{a}$ & $0.442 \pm 0.029 \mathrm{a}$ & $3.131 \pm 0.076^{*}$ & $0.177 \pm 0.002 * a$ \\
\hline \multirow[t]{2}{*}{$\mathrm{SnO}_{2}$} & $1.5 \%$ & $3.069 \pm 0.121$ & $3.305 \pm 0.099$ & $0.102 \pm 0.007$ & $0.304 \pm 0.037$ & $0.117 \pm 0.008$ & $0.421 \pm 0.044$ & $2.598 \pm 0.167$ & $0.154 \pm 0.009$ \\
\hline & $3 \%$ & $2.993 \pm 0.325$ & $3.229 \pm 0.008$ & $0.097 \pm 0.008$ & $0.285 \pm 0.046$ & $0.113 \pm 0.013$ & $0.398 \pm 0.059$ & $2.522 \pm 0.118$ & $0.154 \pm 0.006$ \\
\hline \multirow[t]{3}{*}{$\mathrm{TiO}_{2}$} & $1.5 \%$ & $3.294 \pm 0.558$ & $3.530 \pm 0.104$ & $0.116 \pm 0.017$ & $0.384 \pm 0.002$ & $0.135 \pm 0.020$ & $0.519 \pm 0.018$ & $2.844 \pm 0.407$ & $0.172 \pm 0.002 *$ \\
\hline & $3 \%$ & $3.413 \pm 0.581$ & $3.602 \pm 0.196$ & $0.123 \pm 0.022$ & $0.424 \pm 0.064^{*}$ & $0.137 \pm 0.021$ & $0.561 \pm 0.084 *$ & $3.095 \pm 0.087 *$ & $0.173 \pm 0.010 *$ \\
\hline & $6 \%$ & $3.131 \pm 0.370$ & $3.314 \pm 0.194$ & $0.104 \pm 0.016$ & $0.380 \pm 0.117$ & $0.125 \pm 0.042$ & $0.505 \pm 0.159$ & $3.040 \pm 0.111 *$ & $0.167 \pm 0.004 *$ \\
\hline \multicolumn{2}{|c|}{ Control } & $3.027 \pm 0.213$ & $3.347 \pm 0.234$ & $0.101 \pm 0.004$ & $0.270 \pm 0.018$ & $0.110 \pm 0.015$ & $0.380 \pm 0.032$ & $2.455 \pm 0.191$ & $0.143 \pm 0.007$ \\
\hline
\end{tabular}

* Denotes significant differences between particular treatments and unexposed control, comparisons were performed by Fisher test $(p \leq 0.05)$. Means for concentrations of given

MO-NPs followed by different letters are significantly different at $p \leq 0.05$ according to Fisher test. Each value represents the mean $(n=3) \pm \operatorname{standard~deviation.~Chl~} a-$ chlorophyll $a$,

Chl $b$-chlorophyll $b$, Chls—sum of chlorophyll $a$ and $b$, Car-total carotenoids. 

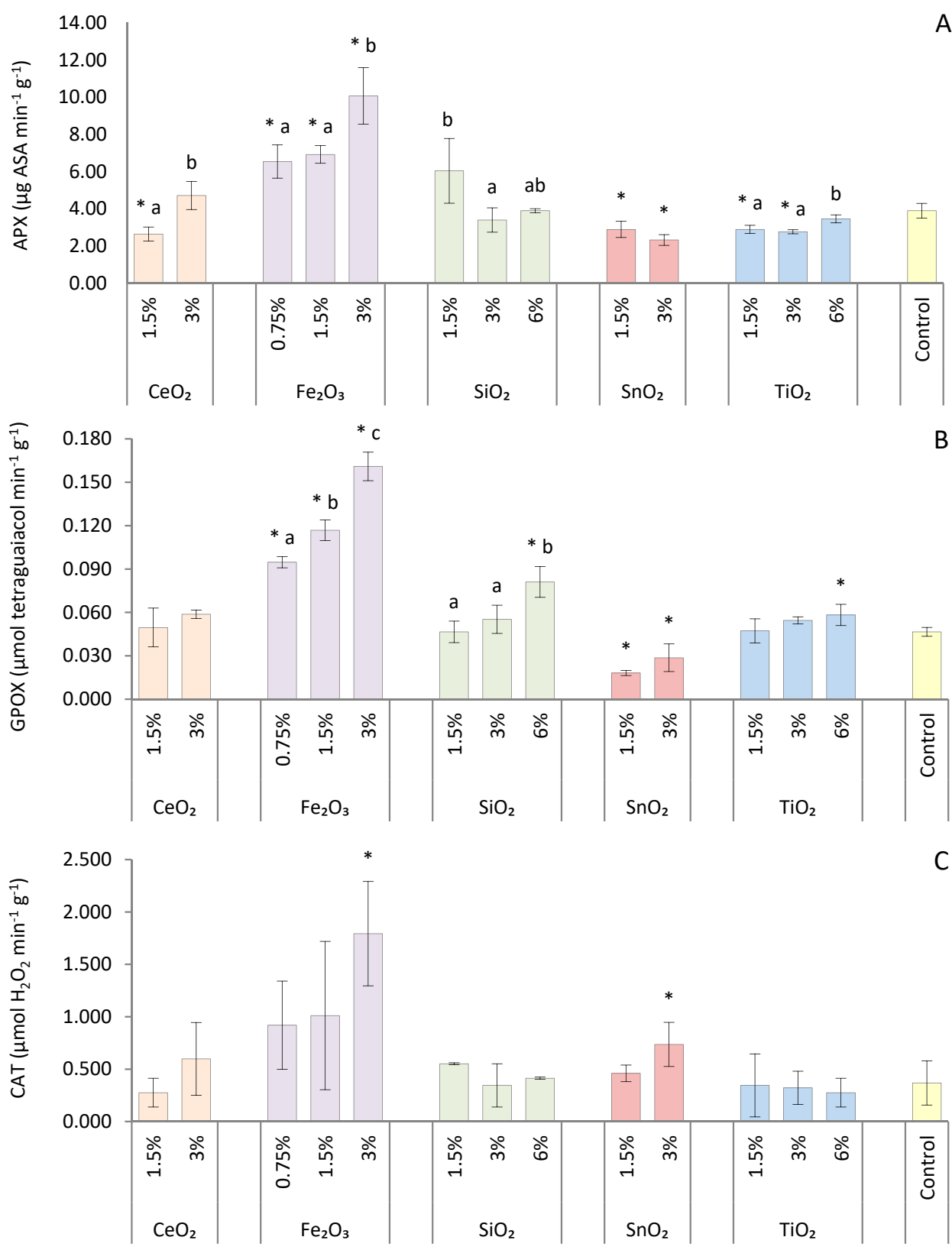

Figure 1. Activity of ascorbate peroxidase (A), guaiacol peroxidase (B), and catalase (C) in oakleaf lettuce seedlings treated with engineered nanoparticles (nano-metal/metalloid oxides; MO-NPs) applied to the leaves at different concentrations. Control plants were sprayed with deionized water. * Denotes significant differences between particular treatments and unexposed control, comparisons were performed by Fisher test $(p \leq 0.05)$. Means $(n=3)$ for concentrations of given MO-NPs followed by different letters are significantly different at $p \leq 0.05$ according to Fisher test. Bars represent standard deviations ( $\pm \mathrm{SD})$.

The level of glutathione (GSH) increased after application of almost all tested MO-NPs (Figure 2A). The only exceptions were plants treated with $\mathrm{SnO}_{2}$-NPs and $1.5 \% \mathrm{Fe}_{2} \mathrm{O}_{3}-\mathrm{NPs}$, where the GSH concentration was similar to that of the control. The greatest increase in GSH content, $91.1 \%$, was observed when foliar spraying with $6 \% \mathrm{TiO}_{2}-\mathrm{NPs}$ was performed. The smallest increase in GSH (by $30.9 \%$ ), but significant in comparison to the control, was observed for treatment with $1.5 \% \mathrm{CeO}_{2}$. The most pronounced effect of NPs on the L-ascorbic acid (LAA) content was shown for $0.75 \%$ and $3 \% \mathrm{Fe}_{2} \mathrm{O}_{3}$-NPs concentrations (Figure 2B), the increase in LAA reached $51.4 \%$ and $54.9 \%$, respectively, in comparison to control plants. All tested concentrations of $\mathrm{TiO}_{2}-\mathrm{NPs}$ also increased the LAA content, 
by $16.7-26.4 \%$. Higher concentrations of $\mathrm{SiO}_{2}-\mathrm{NPs}(3 \%$ and $6 \%$ ) also stimulated LAA biosynthesis in oakleaf lettuce seedlings. All concentrations of $\mathrm{SiO}_{2}-\mathrm{NPs}_{\mathrm{s}}$ and $\mathrm{TiO}_{2}-\mathrm{NPs}$ caused a strong increase in the carotenoid (Car) content in treated plants compared to the control (Figure 2C). This increase in Car was the highest in the case of $1.5 \% \mathrm{SiO}_{2}-\mathrm{NPs}$ (by 104.4\%). Spraying plants with $3 \% \mathrm{Fe}_{2} \mathrm{O}_{3}-\mathrm{NPs}$ also increased carotenoid content by $25.7 \%$. $\mathrm{CeO}_{2}-\mathrm{NPs}, 0.75 \%$ and $1.5 \% \mathrm{Fe}_{2} \mathrm{O}_{3}-\mathrm{NPs}$, and $\mathrm{SnO}_{2}-\mathrm{NPs}$ did not affect the Car concentration in the plants.
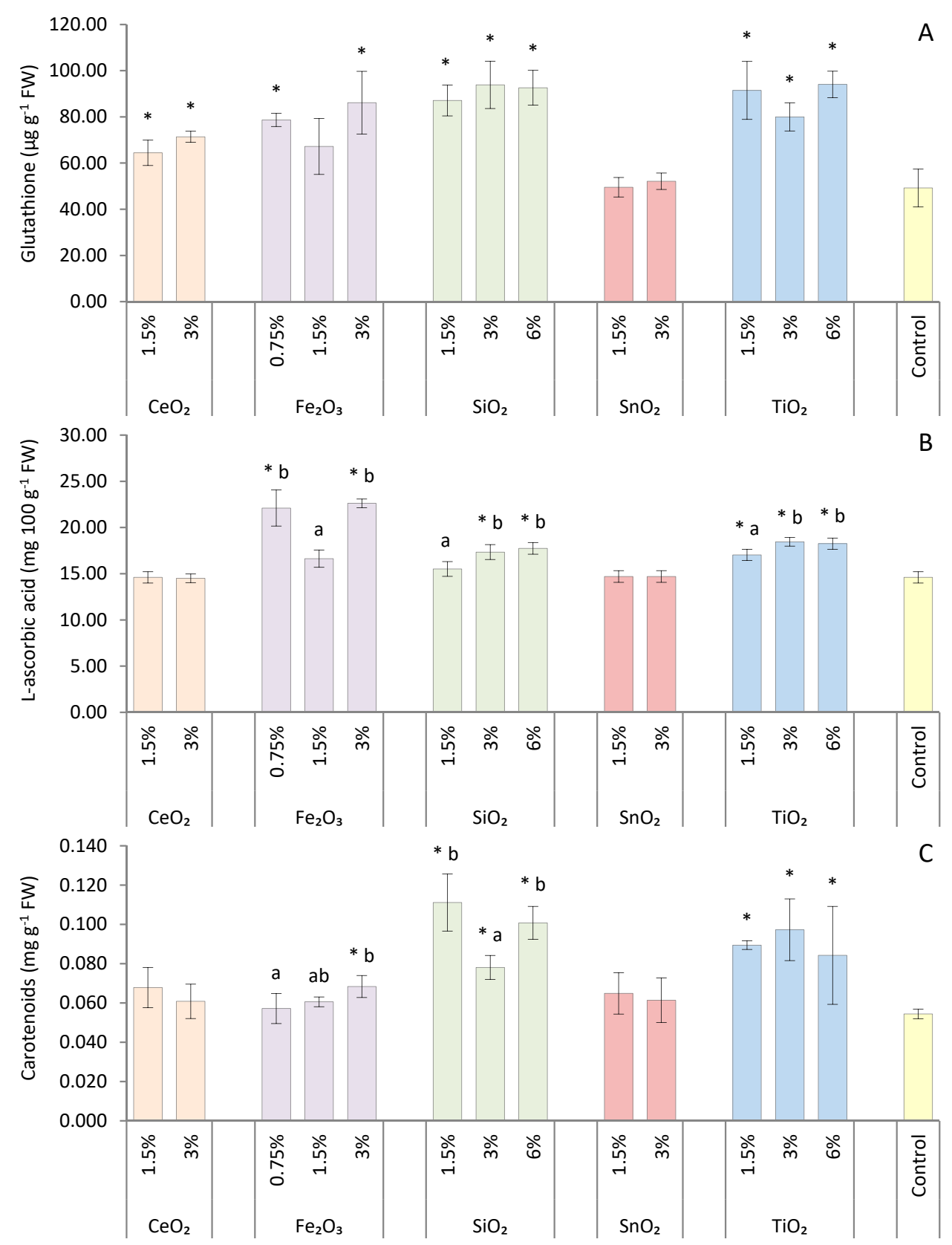

Figure 2. Content of glutathione (A), L-ascorbic acid (B), and carotenoids (C) in oakleaf lettuce seedlings treated with engineered nanoparticles (nano-metal/metalloid oxides; MO-NPs) applied to the leaves at different concentrations. Control plants were sprayed with deionized water. ${ }^{*}$ Denotes significant differences between particular treatments and unexposed control, comparisons were performed by Fisher test $(p \leq 0.05)$. Means $(n=3)$ for concentrations of given MO-NPs followed by different letters are significantly different at $p \leq 0.05$ according to Fisher test. Bars represent standard deviations $( \pm \mathrm{SD})$. 
The application of $\mathrm{SiO}_{2}$-NPs and $\mathrm{TiO}_{2}$-NPs caused an increase in the total phenolic (TP) concentration in oakleaf lettuce plants (Figure 3A). The differences compared to the control were in the range from $24.1 \%$ to $49.3 \%$ for $1.5 \%$ and $6 \%$ suspensions of $\mathrm{TiO}_{2}-\mathrm{NPs}$, respectively, and from $34.8 \%$ to $47.7 \%$ for $1.5 \%$ and $6 \%$ suspensions of $\mathrm{SiO}_{2}-\mathrm{NPs}$, respectively. Additionally, the highest concentrations (3\%) of $\mathrm{CeO}_{2}$-NPs and $\mathrm{Fe}_{2} \mathrm{O}_{3}$-NPs increased the TP content in plants in comparison to the control, by $25.7 \%$ and $16.6 \%$, respectively. Changes in TP content only partially corresponded with the total antioxidant capacity (TAC) of treated lettuce plants (Figure 3B). An increase in TAC was noted for the plants treated with higher concentrations of $\mathrm{CeO}_{2}-\mathrm{NPs}, \mathrm{TiO}_{2}-\mathrm{NPs}$, and $\mathrm{Fe}_{2} \mathrm{O}_{3}-\mathrm{NPs}$. Additionally, $\mathrm{SiO}_{2}$-NPs caused an increase in TAC, but was used only at $1.5 \%$ and $6 \%$ concentrations. The greatest difference between control and treated plants was found for plants treated with $3 \% \mathrm{CeO}_{2}-\mathrm{NPs}$, when the TAC was almost twice as high as in untreated plants.
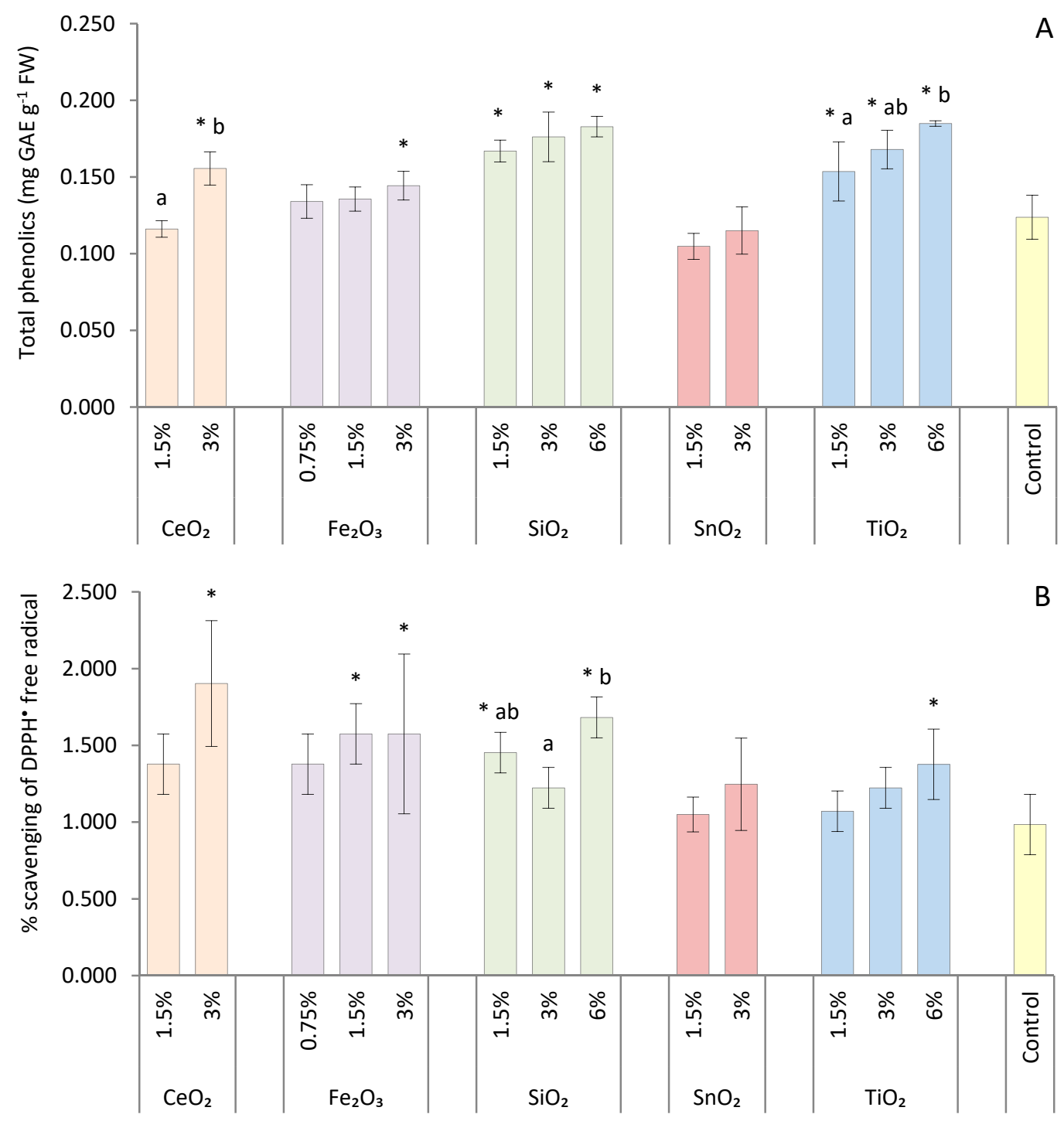

Figure 3. Total phenolic content (A) and total antioxidant capacity (B) of oakleaf lettuce seedlings treated with engineered nanoparticles (nano-metal/metalloid oxides; MO-NPs) applied to the leaves at different concentrations. Control plants were sprayed with deionized water. ${ }^{*}$ Denotes significant differences between particular treatments and unexposed control, comparisons were performed by Fisher test $(p \leq 0.05)$. Means $(n=3)$ for concentrations of given MO-NPs followed by different letters are significantly different at $p \leq 0.05$ according to Fisher test. Bars represent standard deviations ( \pm SD). 
The content of the tested metals/metalloid in plant tissues increased on increasing the concentration of MO-NPs in the treatment suspension (Table 2); however, significant differences were often found only for the highest NP concentrations applied, compared to the control. Only a trace content of cerium was found in the control lettuce, while foliar spraying with $\mathrm{CeO}_{2}-\mathrm{NPs}$ at concentrations of $1.5 \%$ and $3 \%$ increased its content significantly, ca. 3900- and 5500-fold, respectively. Such changes in Fe content were not so spectacular, although significant for the $1.5 \%$ and $3 \% \mathrm{Fe}_{2} \mathrm{O}_{3}-\mathrm{NPs}_{\text {: ca. }} 28-$, $47-$, and 170 -fold higher for $0.75 \%, 1.5 \%$, and 3\%, respectively, compared to control plants. In the case of $\mathrm{SiO}_{2}-\mathrm{NP}$ treatment, the $\mathrm{Si}$ content in the plants was statistically similar to that of the control, even if suspension with $1.5 \%, 3 \%$, and $6 \%$ of this NP was used (these slight increases were in the range 1.1- to 1.7-fold). The Sn content in plants increased significantly, ca. 215- and 333-fold compared to the control, when $1.5 \%$ and $3 \%$ suspensions of $\mathrm{SnO}_{2}-\mathrm{NPs}$, respectively, were used. An increase in Ti content in oakleaf lettuce was found, ca. 144-, 320-, and 647-fold for 1.5\%, 3\%, and 6\% suspensions of $\mathrm{TiO}_{2}-\mathrm{NPs}$, respectively, in comparison to the control, although only differences for $3 \%$ and $6 \%$ suspensions were significant.

Table 2. Content of $\mathrm{Ce}, \mathrm{Fe}, \mathrm{Si}, \mathrm{Sn}$, and $\mathrm{Ti}$ (ppb in extracts) in oakleaf lettuce seedlings depending on engineered nanoparticles (nano-metal/metalloid oxides; MO-NPs) applied to the leaves at different concentrations. Control plants were sprayed with deionized water.

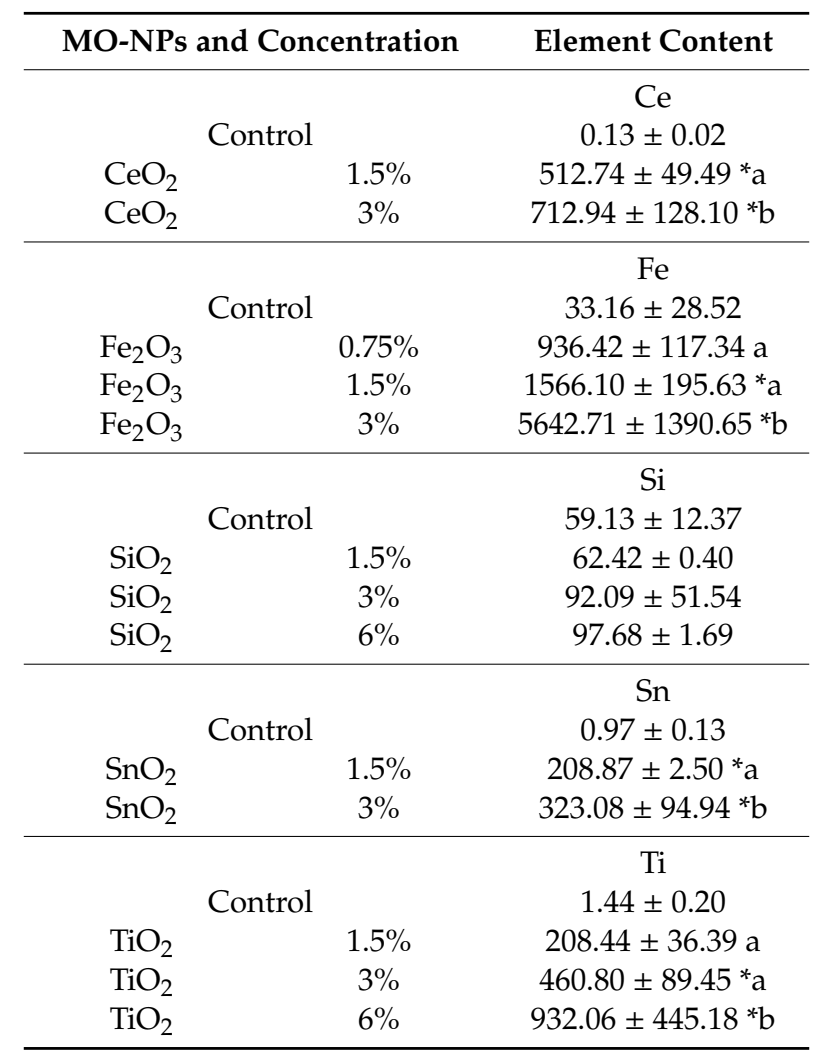

* Denotes significant differences between particular treatments and unexposed control, comparisons were performed by Fisher test $(p \leq 0.05)$. Means for concentrations of given MO-NPs followed by different letters are significantly different at $p \leq 0.05$ according to Fisher test. Each value represents the mean $(n=3) \pm$ standard deviation.

In order to substantiate the effects of MO-NPs applied at different concentrations, the entire dataset concerning antioxidants was analyzed using a PCA-based clustering approach (Figure 4). As a result of the PCA, $87.17 \%$ of the total variation was explained by the first two principal components (PC1 and PC2; 49.79\% and 37.38\%, respectively). The first principal component (PC1) represents mainly enzymes (APX, GPOX, CAT) and L-ascorbic acid content (values of principal components coefficients ranged from -0.805 to -0.941 ), and the second principal component (PC2) represents mainly non-enzymatic antioxidants (glutathione, carotenoids, phenolics; coefficients from 0.803 to 0.889 ). 
Weights of the seven variables with respect to the first two principal components of the PCA analysis are as follows (PC1 and PC2, respectively): APX -0.796 and 0.881 ; GPOX -0.886 and $0.922 ; \mathrm{CAT}-0.648$ and 0.916; L-ascorbic acid -0.751 and 0.760; glutathione -0.295 and 0.939 ; phenolics -0.106 and 0.897 ; carotenoids- -0.003 and 0.785 . All tested concentrations of $\mathrm{Fe}_{2} \mathrm{O}_{3}$-NPs were located on the bottom-left side of the plot with negative factor loadings. The control, $\mathrm{CeO}_{2}-\mathrm{NPs}$, and $\mathrm{SnO}_{2}-\mathrm{NPs}$ had high positive factor loadings with the first component, but negative loadings for $\mathrm{PC} 2$, while the $\mathrm{SiO}_{2}(1.5 \%$ and $6 \%)$ and $\mathrm{TiO}_{2}(6 \%)$ factor loadings were negative for $\mathrm{PC} 1$ but positive for the second component. In the case of $\mathrm{TiO}_{2}-\mathrm{NPs}(1.5 \%$ and $3 \%)$ and $\mathrm{SiO}_{2}-\mathrm{NPs}(3 \%)$, both factor loadings were positive. The bottom-left pool with $\mathrm{Fe}_{2} \mathrm{O}_{3}$-NPs illustrates the experimental combinations that most significantly influenced the antioxidant status of the plants. The bottom-right pool consisted of treatments with a relatively small effect on antioxidant changes in oakleaf lettuce seedlings; it is worth noting that $3 \% \mathrm{CeO}_{2}-\mathrm{NPs}_{\text {sad a }}$ greater influence than $1.5 \% \mathrm{CeO}_{2}-\mathrm{NPs}$. The next two pools contained $\mathrm{SiO}_{2}-\mathrm{NPs}_{\text {s }}$ and $\mathrm{TiO}_{2}-\mathrm{NPs}$, with a clear demonstration that the greatest effect of these NPs was observed for the highest concentration.

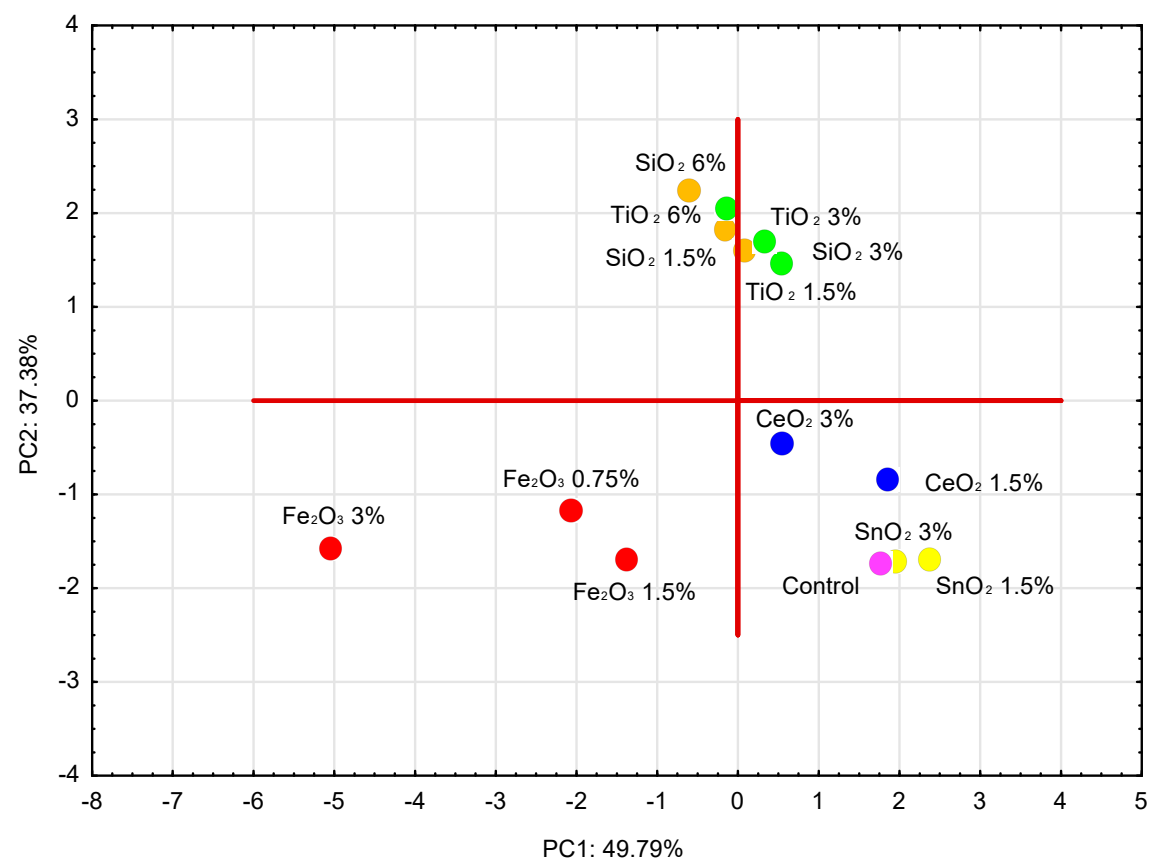

Figure 4. Results of principal component analysis (PCA) analysis for experimental treatments based on the activity of antioxidant enzymes and content of non-enzymatic antioxidant compounds in oakleaf lettuce seedlings.

\section{Discussion}

Several studies have shown that MO-NPs may have both positive and negative effects on plant fresh and dry biomass [24]. The authors mentioned a reduction in shoot biomass of wheat treated with CuO-NPs and ZnO-NPs, cucumber and alfalfa treated with ZnO-NPs, and cotton exposed to $\mathrm{SiO}_{2}-\mathrm{NPs}$ and $\mathrm{CeO}_{2}-\mathrm{NPs} ; \mathrm{ZnO}-\mathrm{NPs}$ treatment caused a decrease in the dry weight (DW) of rapeseed and Indian mustard. On the other hand, $\mathrm{SiO}_{2}-\mathrm{NPs}$ or $\mathrm{CeO}_{2}-\mathrm{NPs}$ increased the $\mathrm{DW}$ of maize and barley plants. Zheng et al. [11] observed a significant increase in the fresh weight (FW) and DW of spinach seedlings treated with $\mathrm{TiO}_{2}$-NPs. In our study, the highest concentration of $\mathrm{Fe}_{2} \mathrm{O}_{3}-\mathrm{NPs}$ reduced the FW of the lettuce seedlings; all concentrations of these MO-NPs increased DW ( $\left.100 \mathrm{~g}^{-1} \mathrm{FW}\right)$. However, total DW (g per shoot) was unaffected by any NPs treatment. Feizi et al. [25] showed that the shoot weight of wheat seedlings was not affected by $\mathrm{Fe}_{2} \mathrm{O}_{3}$-NPs. In contrast, Jeyasubramanian et al. [26] noted a significant increase in spinach biomass ( $F W$ and DW) when $\mathrm{Fe}_{2} \mathrm{O}_{3}-\mathrm{NPs}$ (from 100 to $200 \mathrm{mg} \mathrm{L}^{-1}$ ) were applied to a hydroponic medium. These authors concluded that Fe-NPs could be a source of iron for plants when nanoparticles are used at low application rates. In our study, oakleaf lettuce sprayed with 
$\mathrm{Fe}_{2} \mathrm{O}_{3}$-NPs, especially when the highest concentration of these NPs was applied, suffered from stronger abiotic stress than plants of other treatments-there were a higher level of antioxidant mechanism performance as is shown in further parts of this paper, these plants had smaller leaves, with emerging necrosis spots and they had less water (higher content of dry weight per $100 \mathrm{~g}$ FW together with no affected total dry weight). All together this had to limit the increase in fresh weight and total dry weight of the plants.

We observed an increase in the total chlorophyll content in oakleaf lettuce treated with $\mathrm{SiO}_{2}-\mathrm{NPs}$ (1.5\% and 6\%), $\mathrm{TiO}_{2}-\mathrm{NPs}(3 \%)$, and $\mathrm{Fe}_{2} \mathrm{O}_{3}-\mathrm{NPs}(3 \%)$. Servin et al. [27] found an increase in total chlorophyll content in cucumber leaves when plants were cultivated in soil amended with $750 \mathrm{mg}$ $\mathrm{TiO}_{2}-\mathrm{NPs}$ per kilogram of soil. Additionally, Zheng et al. [11] reported an increase in chlorophyll content in spinach treated with $\mathrm{TiO}_{2}-\mathrm{NPs}$, but only up to a concentration of $2.5 \%$; above this concentration, the chlorophyll level was reduced. $\mathrm{TiO}_{2}$-NPs may promote photosynthesis due to activation of photochemical reactions in chloroplasts, protect chloroplasts from aging, and increase the formation of chlorophyll, Rubisco activity, and photosynthesis intensity [28]. Karimi and Mohsenzadeh [29] showed

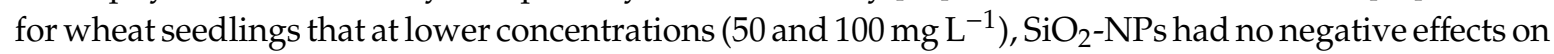
photosynthetic pigments; however, $\mathrm{SiO}_{2}$-NPs applied at high concentrations decreased the chlorophyll content. According to Sun et al. [30], $\mathrm{Si}$ is able to stimulate the expression of genes related to chlorophyll biosynthesis and improve the activity of photosystem II and the electron transfer rate, resulting in an increase in chlorophyll concentration. Results of our study confirm the positive role of $\mathrm{SiO}_{2}-\mathrm{NPs}$ and $\mathrm{TiO}_{2}-\mathrm{NPs}$ (in specific concentrations) on chlorophyll content, which is in agreement with most of the literature data. However, chlorophyll increase did not correlate with increasing concentration of $\mathrm{SiO}_{2}-\mathrm{NPs}$, which is difficult to explain. We also observed higher chlorophyll content in plants treated with $3 \% \mathrm{Fe}_{2} \mathrm{O}_{3}$-NPs. This was a surprise, because the high performance of antioxidant mechanism, lower fresh weight and some other symptoms showed by that plants pointed to $\mathrm{Fe}_{2} \mathrm{O}_{3}$-NPs as a stress stimulus. Perhaps we should look at the physiological functions of Fe in plants. Wang et al. [31] noted that nano-ferric oxide applied to the substrate on which watermelon seedlings grew, in lower doses (20-50 $\mathrm{mg} \mathrm{L}^{-1}$ ), increased chlorophyll level, the authors explained this phenomenon by involvement Fe in the biosynthesis of chlorophyll and its precursors. Several Fe-dependent steps in the chlorophyll biosynthesis have been reported: the conversion of coproporphyrinogen to protoporphyrin IX, Mg-protoporphyrin IX to protochlorophyllide-monomethyl ester and 5-aminolevulinic acid (ALA, tetrapyrrole precursor) synthesis [32,33]. Wang et al. [34] described for muskmelon treated with iron nanoparticles a time-dependent trend of changes in chlorophyll content compared with control; these authors explained a decrease in chlorophyll concentration in first phase by oxidative stress that caused pigment degradation, and the increase in chlorophyll content in third week by absorption of $\mathrm{Fe}$ which is a micronutrient mobilized from applied $\gamma-\mathrm{Fe}_{2} \mathrm{O}_{3}$-NPs and $\mathrm{Fe}_{3} \mathrm{O}_{4}$-NPs and its involvement in various processes occurred in plants.

The ROS induced by NPs can cause oxidative stress in plants; to cope with this stress, plants may activate several antioxidant enzymes which are able to scavenge ROS $[1,10]$. In our experiment, the strongest plant reaction associated with an increase in the activity of antioxidant enzymes was observed for $\mathrm{Fe}_{2} \mathrm{O}_{3}$-NPs, usually with increasing concentration. In agreement with our results, Ghafari and Razmjoo [35] reported that foliar application of nano-iron oxide to wheat increases APX activity. Li et al. [9] showed an increase in peroxidase (POD) activity in corn leaves when plants were treated with $20 \mathrm{mg} \mathrm{L}^{-1} \gamma-\mathrm{Fe}_{2} \mathrm{O}_{3}$-NPs, but at higher concentrations, POD activity was lower or similar to the control. These NPs also caused up-regulation of CAT enzyme activity in corn leaves; the relationship with concentration was similar to that for POD. In our study the highest activity of antioxidant enzymes were observed usually when the highest concentration of $\mathrm{Fe}_{2} \mathrm{O}_{3}$-NPs was applied to the lettuce plants. Siddiqi and Husen [36] presented in their review the antioxidant enzyme response to NPs treatment, and showed that $\mathrm{CeO}_{2}-\mathrm{NPs}$ increased APX activity in roots of coriander, but such a stimulatory effect of $\mathrm{CeO}_{2}-\mathrm{NPs}$ was not observed in our study, moreover, a concentration of $1.5 \% \mathrm{CeO}_{2}$-NPs significantly reduced APX activity in lettuce leaves. We did not observe a significant 
effect of $\mathrm{TiO}_{2}$-NPs on the activity of CAT in lettuce, however, APX activity decreased at $1.5 \%$ and $3 \%$ $\mathrm{TiO}_{2}$-NPs, while GPOX activity increased when $6 \% \mathrm{TiO}_{2}-\mathrm{NPs}$ was applied. As we can see in the next parts of this report, scavenging of $\mathrm{ROS}$ in lettuce plants treated with $\mathrm{TiO}_{2}-\mathrm{NPs}$ was mainly performed by non-enzymatic antioxidants. Mohammadi et al. [37] showed similar to control plants activity of ascorbate peroxidase and guaiacol peroxidase in the seedlings of one chickpea genotype while APX activity decreased in another tested genotype, both were treated with $5 \mathrm{mg} \mathrm{L}^{-1} \mathrm{TiO}_{2}$-NPs. In cucumber, CAT activity increased for all $\mathrm{TiO}_{2}-\mathrm{NPs}$ treatments but APX decreased at high concentrations [27]. Our results also showed some modulation of GPOX activity due to $\mathrm{SiO}_{2}-\mathrm{NPs}$, but it was strictly dependent on the concentration. An interesting observation was the reduction of APX and GPOX activities due to the treatment of plants with all $\mathrm{SnO}_{2}-\mathrm{NPs}$ concentrations, and the increase of CAT activity when $3 \% \mathrm{SnO}_{2}$-NPs were applied; the mechanism of these changes remains unclear, it may result from the delicate balance between the action of these enzymes in the detoxification of ROS [38].

In almost all treatments of our experiment, with the exception of $\mathrm{SnO}_{2}-\mathrm{NPs}$ and $1.5 \% \mathrm{Fe}_{2} \mathrm{O}_{3}-\mathrm{NPs}$, content of glutathione, being important non-enzymatic ROS scavenger, increased in oakleaf lettuce plants. A significant difference in GSH concentration between control lettuce and plants exposed to $\mathrm{TiO}_{2}$-NPs was described by Larue et al. [13]; treated plants contained about two-fold more of this compound. This is in agreement with our findings which showed a significant increase in GSH content in plants treated with these nanoparticles. On the other hand, Jahani et al. [39] did not find any changes in GSH in marigold leaves up to a concentration of $200 \mathrm{mg} \mathrm{L}^{-1} \mathrm{CeO}_{2}-\mathrm{NPs}$; at higher $\mathrm{CeO}_{2}-\mathrm{NPs}$ doses, the GSH content gradually decreased, however, our results showed significant increase in GSH content in plants treated with $\mathrm{CeO}_{2}$-NPs. Our data confirm the role of glutathione in overcoming oxidative stress caused by $\mathrm{TiO}_{2}-\mathrm{NPs}$ and $\mathrm{CeO}_{2}-\mathrm{NPs}$. In our study, the GSH level in oakleaf lettuce plants treated with $0.75 \%$ and $3 \% \mathrm{Fe}_{2} \mathrm{O}_{3}$-NPs was higher than in the control; however, Yoganandham et al. [40] showed a substantial depletion of GSH level in Chlorella vulgaris exposed to different concentrations of $\mathrm{Fe}_{2} \mathrm{O}_{3}$-NPs, but only after $72 \mathrm{~h}$, not after $24 \mathrm{~h}$. They argued that the decrease in GSH may be attributed to strong oxidative stress caused by $\mathrm{Fe}_{2} \mathrm{O}_{3}$-NPs and the consumption of a large amount of GSH in a variety of detoxification processes. We observed an increase in $\mathrm{GSH}$ level due to $\mathrm{SiO}_{2}-\mathrm{NPs}_{\text {treatment. }}$ Tripathi et al. [41] also found a higher GSH content in two maize cultivars treated with $\mathrm{SiO}_{2}-\mathrm{NPs}$. These authors suggests an important role of $\mathrm{SiO}_{2}-\mathrm{NPs}$ in triggering up-regulation of antioxidant defense system in plants, but the exact mechanism of action of these nanoparticles is not much known.

Rico et al. [42] observed a similar level of ascorbate in rice seedlings exposed to $\mathrm{CeO}_{2}-\mathrm{NPs}_{\mathrm{s}}$ comparison to the control, as in our experiment; however, those authors reported a higher total ascorbate content for treatment with the highest concentration of $\mathrm{CeO}_{2}-\mathrm{NPs}\left(500 \mathrm{mg} \mathrm{L}^{-1}\right)$. In the present experiment, higher concentrations of $\mathrm{SiO}_{2}-\mathrm{NPs}$ caused an increase in L-ascorbic acid (LAA) content; this is similar to the results of Tripathi et al. [41] for maize cultivars, where the plants had a higher total ascorbate content due to $\mathrm{SiO}_{2}$-NPs treatment. Again, silicon's ability to regulate antioxidant mechanisms in plants is worth emphasizing [43]. We found a significant increase in LAA content due to $\mathrm{TiO}_{2}-\mathrm{NP}$ treatment. Silva et al. [44] documented total ascorbate changes in wheat leaves and found an increase in the level of this compound for all $\mathrm{TiO}_{2}-\mathrm{NP}$ treatments $\left(5,50\right.$, and $\left.150 \mathrm{mg} \mathrm{L}^{-1}\right)$. These authors pointed that biosynthesis of thiols and ascorbate as well as AsA-GSH cycle are favored in wheat leaves to face $\mathrm{TiO}_{2}-\mathrm{NP}$ toxicity. The large role of non-enzymatic antioxidants with cope the oxidative stress caused by $\mathrm{TiO}_{2}-\mathrm{NPs}$ has also been observed in our experiment. We also found an increase in L-ascorbic acid in plant treated with $0.75 \%$ and $3 \% \mathrm{Fe}_{2} \mathrm{O}_{3}$-NPs. Tavallali [45] noted a higher ascorbic acid content in the aerial parts of purslane when plants were exposed to $\mathrm{Fe}(\mathrm{III})$-aminolevulinic acid (Fe-ALA) nano-complex in comparison to the control.

In the present experiment, the carotenoid content in oakleaf lettuce increased for all concentrations of $\mathrm{TiO}_{2}-\mathrm{NPs}$, which is consistent with the results obtained by Mohammadi et al. [37] who noticed that spraying with $\mathrm{TiO}_{2}$-NPs triggered an increase in the carotenoid level in both genotypes of chickpea seedlings compared to control plants. On the other hand, Larue et al. [13] did not find any effect of foliar exposure of lettuce plants to $\mathrm{TiO}_{2}$-NPs on carotenoid concentration. Our results showed an 
increase in these pigments in oakleaf lettuce due to leaf exposure to $\mathrm{SiO}_{2}-\mathrm{NPs}$ which is consistent with the data presented by Sharifi-Rad et al. [46] who found an increase in the carotenoid content in maize, common bean, hyssop, and black cumin plants treated with $\mathrm{SiO}_{2}-\mathrm{NPs}$ up to a concentration of $2000 \mathrm{mg} \mathrm{L}^{-1}$. High level of carotenoids in oakleaf lettuce plants treated with $3 \% \mathrm{Fe}_{2} \mathrm{O}_{3}$-NPs correlates with overall activity of antioxidant enzymes and higher content of other non-enzymatic antioxidants in plants of that treatment.

The results presented proved that a higher concentration of $\mathrm{CeO}_{2}-\mathrm{NPs}$ applied to oakleaf lettuce caused an increase in total phenolic (TP) content, which is in agreement with the results of Ma et al. [47] who observed a significant increase in anthocyanin synthesis in Arabidopsis thaliana treated with 1000 and $2000 \mathrm{mg} \mathrm{L}^{-1} \mathrm{CeO}_{2}-\mathrm{NPs}$, while no pigment production was evident at $250 \mathrm{mg} \mathrm{L}^{-1}$ treatment. Jahani et al. [39] showed for marigold leaves that the TP content displayed no remarkable variation at 50, 100 , and $200 \mathrm{mg} \mathrm{L}^{-1} \mathrm{CeO}_{2}$-NPs but was enhanced at $400 \mathrm{mg} \mathrm{L}^{-1}$ and peaked at 1600 and $3200 \mathrm{mg} \mathrm{L}^{-1}$. In our experiment, all concentrations of $\mathrm{SiO}_{2}$-NPs up-regulated the synthesis of phenolics, which is similar to the results of Farhangi-Abriz and Torabian [48] who observed that phenolic compounds were enhanced in soybean leaves exposed to $\mathrm{SiO}_{2}-\mathrm{NPs}$, regardless of dose. Vega et al. [49] point to silicon as an agent enhancing biosynthesis of phenolic compounds in barley. We observed that $\mathrm{Fe}_{2} \mathrm{O}_{3}$-NPs at the highest concentration elevated the TP level in oakleaf lettuce. As was shown by Tavallali [45], purslane plants supplied with an Fe-ALA nano-complex at different concentrations had a higher phenolics content than control plants. Foliar exposure of oakleaf lettuce to $\mathrm{TiO}_{2}-\mathrm{NPs}_{\text {caused }}$ in general an increase in TP; similarly Ghorbanpour [50] found that $\mathrm{TiO}_{2}-\mathrm{NPs}$ elevated the level of these compounds (and flavonoids) in common sage at all tested concentrations.

Jahani et al. [39] detected remarkable differences in $\mathrm{DPPH}^{\bullet}$ scavenging activity in marigold at the higher $\mathrm{CeO}_{2}$-NPs concentrations tested (400 to $3200 \mathrm{mg} \mathrm{L}^{-1}$ ); this increment reached up to $18 \%$ compared to the control. Greater total antioxidant capacity in oakleaf lettuce plants treated with the highest concentration of $\mathrm{CeO}_{2}$-NPs was also observed in our experiment, moreover, $6 \% \mathrm{TiO}_{2}$-NPs influenced DPPH radical scavenging activity similarly. Higher concentrations of $\mathrm{Fe}_{2} \mathrm{O}_{3}$-NPs $(1.5 \%$ and $3 \%)$ caused an increase in antioxidant capacity of oakleaf lettuce. This is in agreement with the finding of Tavallali [45] who claimed higher antioxidant activity in purslane plants treated with Fe-ALA nano-complex, whereas the lowest was found in the control group. The effects of $\mathrm{SiO}_{2}$-NPs $(1.5 \%$ and $6 \%$, but not $3 \%)$ were noted in this respect which is partially in agreement with Torabzadeh et al. [51] who observed that the antioxidant capacity of chamomile extracts increased with an increasing concentration of $\mathrm{SiO}_{2}$-NPs. Explaining the absence of significant differences between control plants and those treated with a $3 \% \mathrm{SiO}_{2}-\mathrm{NPs}$ suspension requires further study.

Zhang et al. [52] noticed that the Ce concentrations in cucumber root and shoot samples increased with increasing concentrations of $\mathrm{CeO}_{2}-\mathrm{NPs}$ in the nutrient solutions, especially when smaller ceria particles were used. The Fe content increases in a dose-dependent manner in plants treated with $\mathrm{Fe}_{2} \mathrm{O}_{3}$-NPs in spinach [26] or with Fe-ALA nano-complex in purslane [45]. Le et al. [53] claimed for Bt-transgenic cotton that the $\mathrm{Si}$ content in plant tissues increases with increasing $\mathrm{SiO}_{2}-\mathrm{NP}$ concentration, which was not observed in our experiment on oakleaf lettuce. A dose-response fashion of Ti accumulation in wheat shoots is evident under $\mathrm{TiO}_{2}-\mathrm{NP}$ treatment [54]. No such data are available for Sn.

\section{Conclusions}

In the present study, we evidenced the significant response of the antioxidant mechanism of oakleaf lettuce plants treated with NPs via leaves but it was dependent strongly on the concentration and type of NP applied. An increase in the activity of antioxidant enzymes or in the concentration of antioxidant compounds proved the efficiency of penetration of NPs into the leaves, which caused changes in plant metabolism associated with the occurrence of abiotic stress. The severity of stress depended, however, on the NPs used and their concentrations. It should be emphasized in particular that $\mathrm{Fe}_{2} \mathrm{O}_{3}$-NPs generally increased the activity of APX, GPOX, and CAT, as well as the GSH, LAA, 
carotenoid, and total phenolic content, and the total antioxidant activity of lettuce plants. The result of a significant effect of Fe on most internal parameters should be linked to the most important role of iron in plant physiology compared to the other elements tested. An increase in the content of non-enzymatic antioxidative compounds was also clearly visible after the use of $\mathrm{TiO}_{2}-\mathrm{NPs}$ and $\mathrm{SiO}_{2}-\mathrm{NPs}$, or in the case of GSH and TP for $\mathrm{CeO}_{2}$-NPs. The smallest changes in non-enzymatic compounds in plants occurred due to the use of $\mathrm{SnO}_{2}$-NPs. However, $\mathrm{SnO}_{2}$-NPs decreased activity of APX and GPOX, while CAT activity was elevated. Tin showed a very interesting result which should help in understanding its role in plant stress physiology. The type of research undertaken allows us to better understand the fate of NPs in the environment and biological systems. However, more studies are still needed concerning the plant's antioxidant system and overall stress response when exposed to various NPs, and such information will be useful for ecological and human health risk assessments.

Author Contributions: R.J. and A.K. performed the experiment and wrote the manuscript; S.S. carried out the analysis of metals/metalloid in plant samples; A.S. and S.S. helped in the writing of some parts of the manuscript; A.S. and R.P. critically evaluated the manuscript. All authors have read and agreed to the published version of the manuscript.

Funding: This work was financially supported by the Ministry of Science and Higher Education of the Republic of Poland. This paper was also supported by project CZ.02.1.01/0.0/0.0/16_017/0002334 of the Research Infrastructure for Young Scientists, co-financed from the Operational Program for Research, Development and Education, and the Ministry of Education of the Czech Republic.

Conflicts of Interest: The authors declare no conflict of interest.

\section{References}

1. Sanzari, I.; Leone, A.; Ambrosone, A. Nanotechnology in plant science: To make a long story short. Front. Bioeng. Biotechnol. 2019, 7, 120. [CrossRef] [PubMed]

2. Masarovičová, E.; Král'ová, K. Metal nanoparticles and plants. Ecol. Chem. Eng. S 2013, 20, 9-22.

3. Nowack, B.; Bucheli, T.D. Occurrence, behavior and effects of nanoparticles in the environment. Environ. Pollut. 2007, 150, 5-22. [CrossRef]

4. Khodakovskaya, M.V.; de Silva, K.; Biris, A.S.; Dervishi, E.; Villagarcia, H. Carbon nanotubes induce growth enhancement of tobacco cells. ACS Nano 2012, 6, 2128-2135. [CrossRef] [PubMed]

5. Navarro, N.; Baun, A.; Behra, R.; Hartmann, N.B.; Filser, J.; Miao, A.-J.; Quigg, A.; Santschi, P.H.; Sigg, L. Environmental behavior and ecotoxicity of engineered nanoparticles to algae, plants, and fungi. Ecotoxicology 2008, 17, 372-386. [CrossRef] [PubMed]

6. García-Gómez, C.; Fernández, M.D. Impacts of metal oxide nanoparticles on seed germination, plant growth and development. In Comprehensive Analytical Chemistry, Analysis, Fate, and Toxicity of Engineered Nanomaterials in Plants; Verma, S.K., Das, A.K., Eds.; Elsevier: Amsterdam, The Netherlands, 2019; Volume 84, pp. 75-124.

7. Milewska-Hendel, A.; Zubko, M.; Stróż, D.; Kurczyńska, E.U. Effect of nanoparticles surface charge on the Arabidopsis thaliana (L.) roots development and their movement into the root cells and protoplasts. Int. J. Mol. Sci. 2019, 20, 1650. [CrossRef] [PubMed]

8. Rico, C.M.; Majumdar, S.; Duarte-Gardea, M.; Peralta-Videa, J.R.; Gardea-Torresdey, J.L. Interaction of nanoparticles with edible plants and their possible implications in the food chain. J. Agric. Food Chem. 2011, 59, 3485-3498. [CrossRef]

9. Li, J.; Hu, J.; Ma, C.; Wang, Y.; Wu, C.; Huang, J.; Xing, B. Uptake, translocation and physiological effects of magnetic iron oxide $\left(\gamma-\mathrm{Fe}_{2} \mathrm{O}_{3}\right)$ nanoparticles in corn (Zea mays L.). Chemosphere 2016, 159, 326-334. [CrossRef]

10. Das, K.; Roychoudhury, A. Reactive oxygen species (ROS) and response of antioxidants as ROS-scavengers during environmental stress in plants. Front. Environ. Sci. 2014, 2, 53. [CrossRef]

11. Zheng, L.; Hong, F.; Lu, S.; Liu, C. Effect of nano- $\mathrm{TiO}_{2}$ on strength of naturally aged seeds and growth of spinach. Biol. Trace Elem. Res. 2005, 104, 83-92. [CrossRef]

12. Larue, C.; Castillo-Michel, H.; Sobanska, S.; Cécillon, L.; Bureau, S.; Barthès, V.; Ouerdane, L.; Carrière, M.; Sarret, G. Foliar exposure of the crop Lactuca sativa to silver nanoparticles: Evidence for internalization and changes in Ag speciation. J. Hazard. Mater. 2014, 264, 98-106. [CrossRef] [PubMed] 
13. Larue, C.; Castillo-Michel, H.; Sobanska, S.; Trcera, N.; Sorieul, S.; Cécillon, L.; Ouerdane, L.; Legros, S.; Sarret, G. Fate of pristine $\mathrm{TiO}_{2}$ nanoparticles and aged paint-containing $\mathrm{TiO}_{2}$ nanoparticles in lettuce crop after foliar exposure. J. Hazard. Mater. 2014, 273, 17-26. [CrossRef] [PubMed]

14. Lichtenthaler, H.K.; Wellburn, A.R. Determinations of total carotenoids and chlorophylls a and b of leaf extracts in different solvents. Biochem. Soc. Trans. 1983, 603, 591-592. [CrossRef]

15. Aebi, H. Catalase in vitro. Methods Enzymol. 1984, 105, 121-126. [PubMed]

16. Nakano, Y.; Asada, K. Hydrogen peroxide is scavenged by ascorbate specific peroxidase in spinach chloroplasts. Plant Cell Physiol. 1981, 22, 867-880.

17. Zhang, Z.; Pang, X.; Duan, X.; Ji, Z.L.; Jiang, Y. Role of peroxidase in anthocyanine degradation in litchi fruit pericarp. Food Chem. 2005, 90, 47-52. [CrossRef]

18. Guri, A. Variation in glutathione and ascorbic acid content among selected cultivars of Phaseolus vulgaris prior to and after exposure to ozone. Can. J. Plant Sci. 1983, 63, 733-737. [CrossRef]

19. Krełowska-Kułas, M. Badanie Jakości Produktów Spożywczych [The Study of Food Quality]; PWN: Warsaw, Poland, 1993.

20. Djeridane, A.; Yousfi, M.; Nadjemi, B.; Boutassouna, D.; Stocker, P.; Vidal, N. Antioxidant activity of some Algerian medicinal plants extracts containing phenolic compound. Food Chem. 2006, 97, 654-660. [CrossRef]

21. Molyneux, P. The use of the stable free radical diphenylpicrylhydrazyl (DPPH) for estimating antioxidant activity. Songklanakarin J. Sci. Technol. 2004, 26, 211-219.

22. Barros, J.A.; de Souza, P.F.; Schiavo, D.; Nóbrega, J.A. Microwave-assisted digestion using diluted acid and base solutions for plant analysis by ICP OES. J. Anal. Atom. Spectrom. 2016, 31, 337-343. [CrossRef]

23. Kalisz, A.; Sękara, A.; Smoleń, S.; Grabowska, A.; Gil, J.; Komorowska, M.; Kunicki, E. Survey of 17 elements, including rare earth elements, in chilled and non-chilled cauliflower cultivars. Sci. Rep. 2019, 9, 5416. [CrossRef]

24. Rizwan, M.; Ali, S.; Qayyum, M.F.; Ok, Y.S.; Adrees, M.; Ibrahim, M.; Zia-Ur-Rehman, M.; Farid, M.; Abbas, F. Effect of metal and metal oxide nanoparticles on growth and physiology of globally important food crops: A critical review. J. Hazard. Mater. 2017, 322, 2-16. [CrossRef] [PubMed]

25. Feizi, H.; Moghaddam, P.R.; Shahtahmassebi, N.; Fotovat, A. Assessment of concentrations of nano and bulk iron oxide particles on early growth of wheat (Triticum aestivum L.). Annu. Res. Rev. Biol. 2013, 3, 752-761.

26. Jeyasubramanian, K.; Thoppeya, U.U.G.; Hikkua, G.S.; Selvakumara, N.; Subramaniab, A.; Krishnamoorthy, K. Enhancement in growth rate and productivity of spinach grown in hydroponics with iron oxide nanoparticles. RSC Adv. 2016, 6, 15451. [CrossRef]

27. Servin, A.D.; Morales, M.I.; Castillo-Michel, H.; Hernandez-Viezcas, J.A.; Munoz, B.; Zhao, L.; Nunez, J.E.; Peralta-Videa, J.R.; Gardea-Torresdey, J.L. Synchrotron verification of $\mathrm{TiO}_{2}$ accumulation in cucumber fruit: A possible pathway of $\mathrm{TiO}_{2}$ nanoparticle transfer from soil into the food chain. Environ. Sci. Technol. 2013, 47, 11592-11598. [CrossRef] [PubMed]

28. Du, W.; Tan, W.; Peralta-Videa, J.B.; Gardea-Torresdey, J.L.; Ji, R.; Yin, Y.; Guo, H. Interaction of metal oxide nanoparticles with higher terrestrial plants: Physiological and biochemical aspects. Plant Physiol. Biochem. 2017, 110, 210-225. [CrossRef]

29. Karimi, J.; Mohsenzadeh, S. Effects of silicon oxide nanoparticles on growth and physiology of wheat seedlings. Russ. J. Plant Physiol. 2016, 63, 119-123. [CrossRef]

30. Sun, D.; Hussain, H.I.; Yi, Z.; Rookes, J.E.; Kong, L.; Cahill, D.M. Mesoporous silica nanoparticles enhance seedling growth and photosynthesis in wheat and lupin. Chemosphere 2016, 152, 81-91. [CrossRef]

31. Wang, M.; Liu, X.; Hu, J.; Li, J.; Huang, J. Nano-ferric oxide promotes watermelon growth. J. Biomater. Nanobiotechnol. 2015, 6, 160-167. [CrossRef]

32. Miller, G.W.; Jen Huang, I.; Welkiel, G.W.; Pushnik, J.C. Function of iron in plants with special emphasis on chloroplasts and photosynthetic activity. In Iron Nutrition in Soils and Plants; Abadia, J., Ed.; Kluwer Academic Publishers: Berlin, Germany, 1995; pp. 19-28.

33. Briat, J.-F.; Dubos, C.; Gaymard, F. Iron nutrition, biomass production, and plant product quality. Trends Plant Sci. 2015, 20, 33-40. [CrossRef]

34. Wang, Y.; Wang, S.; Xu, M.; Xiao, L.; Dai, Z.; Li, J. The impacts of $\gamma-\mathrm{Fe}_{2} \mathrm{O}_{3}$ and $\mathrm{Fe}_{3} \mathrm{O}_{4}$ nanoparticles on the physiology and fruit quality of muskmelon (Cucumis melo) plants. Environ. Pollut. 2019, 249, 1011-1018. [CrossRef]

35. Ghafari, H.; Razmjoo, J. Effect of foliar application of nano-iron oxidase, iron chelate and iron sulphate rates on yield and quality of wheat. Int. J. Agron. Plant Prod. 2013, 4, 2997-3003. 
36. Siddiqi, K.S.; Husen, A. Plant response to engineered metal oxide nanoparticles. Nanoscale Res. Lett. 2017, 12, 92. [CrossRef] [PubMed]

37. Mohammadi, R.; Maali-Amiri, R.; Mantrib, N.L. Effect of $\mathrm{TiO}_{2}$ nanoparticles on oxidative damage and antioxidant defense systems in chickpea seedlings during cold stress. Russ. J. Plant Physiol. 2014, 61, 768-775. [CrossRef]

38. Apel, K.; Hirt, H. Reactive oxygen species: Metabolism, oxidative stress, and signal transduction. Ann. Rev. Plant Biol. 2004, 55, 373-399. [CrossRef] [PubMed]

39. Jahani, S.; Saadatmand, S.; Mahmoodzadeh, H.; Khavari-Nejad, R.A. Effects of cerium oxide nanoparticles on biochemical and oxidative parameters in marigold leaves. Toxicol. Environ. Chem. 2018, 100, 677-692. [CrossRef]

40. Yoganandham, S.T.; Ravindranath, R.R.S.; Sathyamoorthy, G.; Renuka, R.R.; Lakshminarayanan, A. Hematite nanoparticles: Synthesis, characterization and aquatic ecotoxicity effects. Res. J. Biotech. 2019, 14, 21-30.

41. Tripathi, D.K.; Singh, S.; Singh, V.P.; Prasad, S.M.; Chauhan, D.K.; Dubey, N.K. Silicon nanoparticles more efficiently alleviate arsenate toxicity than silicon in maize cultiver and hybrid differing in arsenate tolerance. Front. Environ. Sci. 2016, 4, 46. [CrossRef]

42. Rico, C.M.; Hong, J.; Morales, M.I.; Zhao, L.; Barrios, A.C.; Zhang, J.-Y.; Peralta-Videa, J.R.; Gardea-Torresdey, J.L. Effect of cerium oxide nanoparticles on rice: A study involving the antioxidant defense system and in vivo fluorescence imaging. Environ. Sci. Technol. 2013, 47, 5635-5642. [CrossRef]

43. Kim, Y.-H.; Khan, A.L.; Waqas, M.; Lee, I.-J. Silicon regulates antioxidant activities of crop plants under abiotic-induced oxidative stress: A review. Front Plant Sci. 2017, 8, 510. [CrossRef]

44. Silva, S.; de Oliveira, J.M.P.F.; Dias, M.C.; Silva, A.M.S.; Santos, C. Antioxidant mechanisms to counteract $\mathrm{TiO}_{2}$-nanoparticles toxicity in wheat leaves and roots are organ dependent. J. Hazard. Mat. 2019, 380, 120889. [CrossRef] [PubMed]

45. Tavallali, V. Effects of iron nano-complex and Fe-EDDHA on bioactive compounds and nutrient status of purslane plants. Int. Agrophys. 2018, 32, 411-419. [CrossRef]

46. Sharifi-Rad, A.; Sharifi-Rad, M.; Teixeira da Silva, J.A. Morphological, physiological and biochemical responses of crops (Zea mays L., Phaseolus vulgaris L.), medicinal plants (Hyssopus officinalis L., Nigella sativa L.), and weeds (Amaranthus retroflexus L., Taraxacum officinale F. H. Wigg) exposed to $\mathrm{SiO}_{2}$ nanoparticles. J. Agric. Sci. Tech. 2016, 18, 1027-1040.

47. Ma, C.; Chhikara, S.; Xing, B.; Musante, C.; White, J.C.; Dhankher, O.P. Physiological and molecular response of Arabidopsis thaliana (L.) to nanoparticle cerium and indium oxide exposure. ACS Sustain. Chem. Eng. 2013, 1, 768-778. [CrossRef]

48. Farhangi-Abriz, S.; Torabian, S. Nano-silicon alters antioxidant activities of soybean seedlings under salt toxicity. Protoplasma 2018, 255, 953-962. [CrossRef] [PubMed]

49. Vega, I.; Nikolic, M.; Pontigo, S.; Godoy, K.; de La Luz Mora, M.; Cartes, P. Silicon improves the production of high antioxidant or structural phenolic compounds in barley cultivars under aluminum stress. Agronomy 2019, 9, 388. [CrossRef]

50. Ghorbanpour, M. Major essential oil constituents, total phenolics and flavonoids content and antioxidant activity of Salvia officinalis plant in response to nano-titanium dioxide. Ind. J. Plant Physiol. 2015, 20, 249-256. [CrossRef]

51. Torabzadeh, D.; Hassanpour, H.; Asgarpanah, J.; Rezayian, M. Nanoparticles induced antioxidative compounds in Matricaria chamomilla. Iran. J. Plant Physiol. 2019, 9, 2955-2961.

52. Zhang, Z.; He, X.; Zhang, H.; Ma, Y.; Zhang, P.; Ding, Y.; Zhao, Y. Uptake and distribution of ceria nanoparticles in cucumber plants. Metallomics 2011, 3, 816-822. [CrossRef]

53. Le, V.N.; Rui, Y.; Gui, X.; Li, X.; Liu, S.; Ha, Y. Uptake, transport, distribution and bio-effects of $\mathrm{SiO}_{2}$ nanoparticles in Bt-transgenic cotton. J. Nanobiotechnol. 2014, 12, 50. [CrossRef]

54. Jiang, F.; Shen, Y.; Ma, C.; Zhang, X.; Cao, W.; Rui, Y. Effects of $\mathrm{TiO}_{2}$ nanoparticles on wheat (Triticum aestivum L.) seedlings cultivated under super-elevated and normal $\mathrm{CO}_{2}$ conditions. PLoS ONE 2017, 12, e0178088. [CrossRef] [PubMed] 